OPEN ACCESS

Edited by:

Jacob Van Etten,

Bioversity International, Italy

Reviewed by:

Nicholas R. Magliocca,

University of Alabama, United States

Gabriel da Silva Medina,

University of Brazilia, Brazil

*Correspondence:

Ken E. Giller

ken.giller@wur.n

Specialty section:

This article was submitted to Land, Livelihoods and Food Security,

a section of the journal

Frontiers in Sustainable Food Systems

Received: 29 June 2021 Accepted: 06 September 2021

Published: 06 October 2021

Citation:

van Vliet JA, Slingerland MA, Waarts YR and Giller KE (2021) A Living Income for Cocoa Producers in Côte d'voire and Ghana? Front. Sustain. Food Syst. 5:732831. doi: 10.3389/fsufs.2021.732831

\section{A Living Income for Cocoa Producers in Côte d'Ivoire and Ghana?}

\author{
Jiska A. van Vliet ${ }^{1}$, Maja A. Slingerland ${ }^{1}$, Yuca R. Waarts ${ }^{2}$ and Ken E. Giller ${ }^{1 *}$ \\ ${ }^{1}$ Plant Production Systems, Wageningen University and Research, Wageningen, Netherlands, ${ }^{2}$ Wageningen Economic \\ Research, Wageningen University and Research, Wageningen, Netherlands
}

It is often claimed that cocoa producers are poor, but the extent of their poverty is rarely defined. We analyzed six data sets derived from household questionnaires of 385-88,896 cocoa producers in Côte d'Ivoire and Ghana. Across all data sets, many households (30-58\%) earn a gross income below the World Bank extreme poverty line and the majority (73-90\%) do not earn a Living Income. Households with less income per person per day generally achieve lower cocoa yields, consist of more household members, have a smaller land size available, and rely more on cocoa income than households with higher incomes. When comparing the effects of increasing prices and yields on gross income, yield increases lead to larger benefits especially for the poorest households. Doubling the cocoa price would leave 15-25\% of households with a gross income below the extreme poverty line and 53-65\% below the Living Income benchmark. At yields of $600 \mathrm{~kg} / \mathrm{ha}$, against current yields around $300 \mathrm{~kg} / \mathrm{ha}$, these percentages are reduced to $7-11$ and $48-62 \%$, respectively, while at yields of $1,500 \mathrm{~kg} / \mathrm{ha}$ only $1-2 \%$ of households remain below the extreme poverty line and $13-20 \%$ below the Living Income benchmark. If we assume that the production costs of achieving a yield of $1,500 \mathrm{~kg} / \mathrm{ha}$ are $30 \%$ of revenue, still only $2-4 \%$ of households earn a net income below the extreme poverty line and $25-32 \%$ below the Living Income benchmark. Whilst sustainable intensification of cocoa production is undoubtedly a strong approach to increase cocoa yields and farmer incomes, achieving this does not come without pitfalls. The poorer households face multiple barriers to invest in cocoa production. A better understanding of cocoa producing households and the resources available to them, as well as the opportunity for alternative income generation, is required to tailor options to increase their income. The utility and interpretability of future household surveys would be drastically improved if definitions and variables addressed were approached in a standardized way.

Keywords: smallholder farms, poverty benchmarks, sustainable intensification, household surveys, cocoa production

\section{INTRODUCTION}

Most of the world's cocoa originates from West Africa, with Côte d'Ivoire and Ghana contributing more than $60 \%$ of all cocoa (ICCO, 2019). Virtually all cocoa in West Africa is produced by smallholder farmers, many of whom are poor (e.g., Fountain and Hütz-Adams, 2018; Cargill, 2019; Fairtrade, 2020). Both Côte d'Ivoire and Ghana have taken a variety of measures to make cocoa more profitable for farmers, through the Conseil du Café-Cacao and the Ghana Cocoa Board (Cocobod), respectively. 
In the early 2000s, Ghana offered farmers improved varieties, subsidized fertilizer and free pest and disease control, set a panterritorial producer price, and simultaneously increased farmers share in cocoa export prices. In a context of high world market prices these measures resulted in increased productivity and a drop in poverty levels between 1990 and 2005 (Vigneri and Kolavalli, 2018). In Côte d'Ivoire the government also fixed cocoa prices relative to the international market to assure farmers a stable income with positive effects between 1979 and 1999 (Coulibaly and Erbao, 2019), but invested little in input supply. With time cocoa could no longer benefit from the natural fertility of soils on which it was planted (the so-called "forest rent" Ruf and Schroth, 2004). As a consequence productivity declined, and since 2000 as costs of production increased farmers became poorer both in Côte d'Ivoire and Ghana (Odijie, 2016). In 2014, 10 of the largest chocolate multinationals introduced a cocoa sustainability scheme called CocoaAction, jointly investing 500 million USD in sustainable cocoa production in West Africa to support cocoa planters and counteract these trends, out of fear of insufficient supply of cocoa beans (Odijie, 2018). In 2019, the governments of Côte d'Ivoire and Ghana introduced a premium on the export price of cocoa for the 2020/2021 season, known as the Living Income Differential, of USD 400 per ton. The question is whether all these efforts have allowed cocoa farmers to reach a living income nowadays.

Many local and international organizations, together with companies involved in the procurement or processing of cocoa, have committed to ensure increased incomes of cocoa producers in their supply chains. For instance, Barry Callebaut in their "Forever Chocolate" have resolved to lift more than half a million cocoa farmers out of poverty by 2025 (Barry Callebaut, 2018). Cargill mentions that "Many farmers struggle to achieve a Living Income and as a result face being trapped in a cycle of poverty" and suggests ways in which they help farmers increase their income through the Cocoa Promise programme (Cargill, 2019). Net income from cocoa and from other sources are among the key performance indicators of the Cocoa Life Programme (Mondelēz International, 2020). A focal area of the "Cocoa for Generations" programme is to improve farmers' incomes (Mars, 2020).

The involvement of confectionary companies in issues of poverty and labor rights has a rich tradition. Two famous chocolatiers, the Rowntree and Cadbury families, were Quaker industrial philanthropists who cared for their workers. Seebohm Rowntree was the first to use a "cost of basic needs" approach to derive a poverty line for workers at the end of the nineteenth century (Rowntree, 1901; Ravallion, 2000, 2008). It is less clear whether these companies ever considered the farmers and farm workers who produced the cocoa they used to make chocolate in their factories, as is the focus today.

Today, many trading and confectionary companies as well as other organizations such as Solidaridad, FairTrade, and CocoaBarometer report on statistics such as current average cocoa farmer incomes or the proportion of producers who live in poverty. However, the metrics they present vary. First, different benchmarks to define poverty are used. Second, the methods used to calculate the income of cocoa producers differ. Poverty is measured against different standards. In 1990, the World Bank introduced the concept of the "global poverty line" to allow for cross-country comparison and aggregation, based on national poverty lines for a number of lowest income countries at that time (World Bank, 1990). Based on this report, the "1 dollar a day" standard to measure extreme poverty, which was expressed in Purchasing Power Parity (PPP) 1985, became accepted by the World Bank and internationally (World Bank, 1990; Ravallion et al., 2009). Purchasing Power Parity is a way to convert monetary values to a theoretical common currency, taking into account the relative cost of living and inflation rates in different countries. Based on a larger set of national poverty lines and new PPP conversion factors, the 1 \$ a day threshold was revised to 1.25 \$ (PPP 2005) per capita per day in 2009 (Ravallion et al., 2009), and again to 1.90 \$ (PPP 2011) per capita per day in 2015 (Ferreira et al., 2016). This is the current global extreme poverty line. Indeed, Barry Callebaut is using this poverty line as a benchmark for their ambition to lift half a million farmers out of poverty by 2025 (Barry Callebaut, 2021).

Recently, the concept of "Living Income" has gained attention as an income benchmark, especially in the context of export commodities such as cocoa (e.g., Fountain and Hütz-Adams, 2015, 2018; Fairtrade, 2018; Tony's Chocolonely, 2018; Cargill, 2019). The Living Income Community of Practice, defines Living Income as: "The net annual income required for a household in a particular place to afford a decent standard of living for all members of that household. Elements of a decent standard of living include: food, water, housing, education, healthcare, transport, clothing, and other essential needs including provision for unexpected events" (Living Income Community of Practice, 2020). A Living Income thus addresses the basic human rights to food, shelter, housing, and education (Van De Ven et al., 2020). The Living Income benchmark for a specific country or region generally lies above the national or global poverty lines, as more items are considered to be required for a decent standard of living than what is usually included in the "consumption basket" used to calculate the poverty lines (Van De Ven et al., 2020).

There is a rich literature on the role of agricultural production in smallholder livelihoods (e.g., Boserup, 1965; Ellis, 1993), that remains largely unexplored in the case of cocoa producers. Of particular importance, is the recognition that smallholders often depend on a diverse range of income streams, both on and off the farm (Ellis, 1998; Ellis and Freeman, 2004). The most recent and comprehensive study of cocoa production to date in West Africa is that conducted by the Royal Tropical Institute (KIT) (Bymolt et al., 2018). Based on our reading of the literature, we summarize our understanding of the relationships among variables that determine the income of cocoa producing households in Figure 1. Cocoa is key to the livelihoods of smallholder cocoa producers in both Côte d'Ivoire and Ghana, representing roughly two-thirds of income in both countries (Bymolt et al., 2018), so the farm area cropped with cocoa, the cocoa yield, and the price farmers receive for their cocoa all have a large effect on total household income.

There is potentially a self-amplifying mechanism between household income, input use, and cocoa yield (Figure 1) which is positive for wealthier households. Unfortunately, the same 


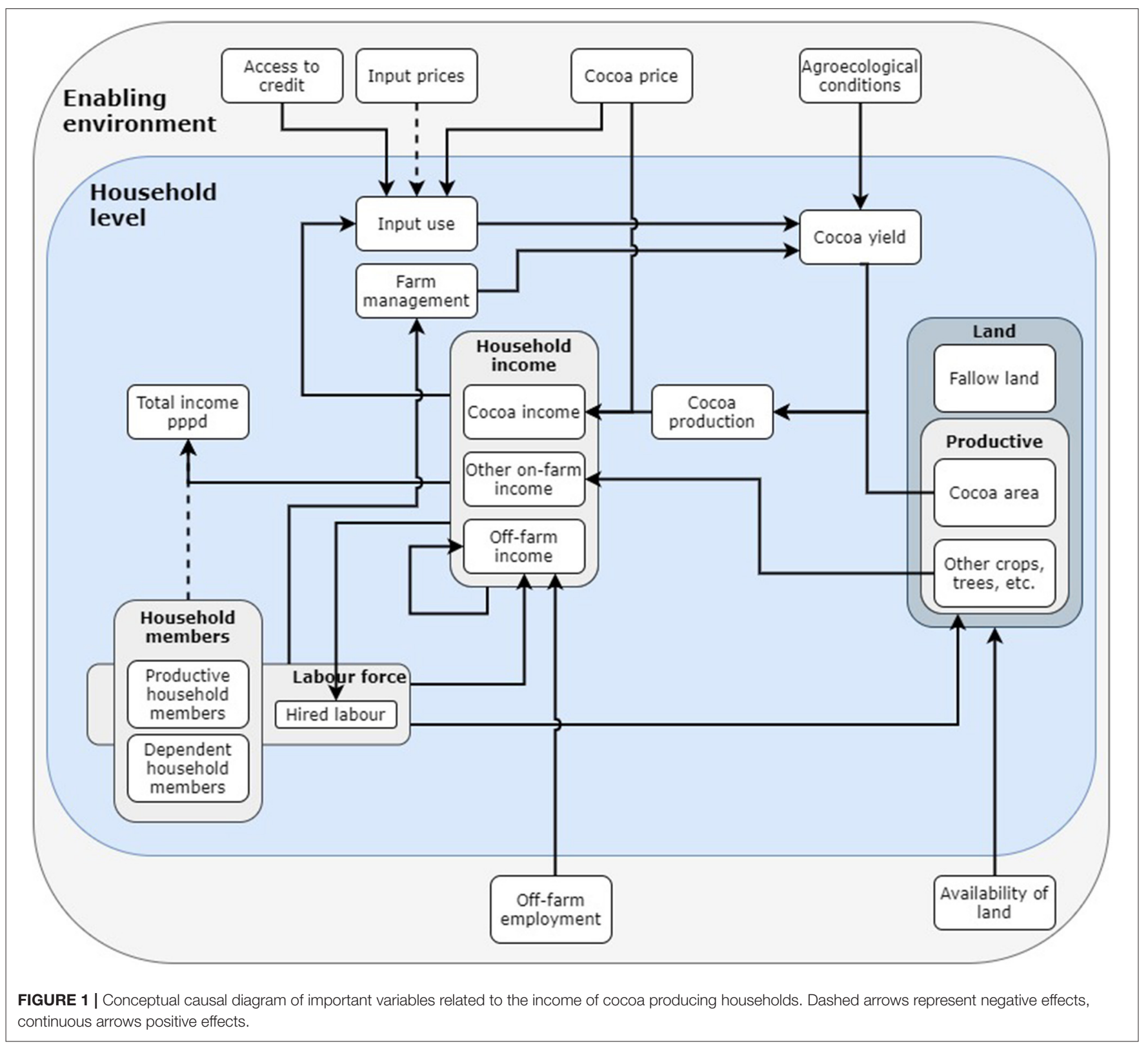

mechanism can bring poorer farmers into a negative spiral or poverty trap where their cocoa area and yield is too small to earn a decent income from cocoa, while their lack of income prevents them from being able to invest in inputs to improve their yield. Similarly, households with a higher income are more likely to be able to afford to hire labor, giving them access to a larger labor force, and therefore a higher income (Figure 1). Availability of land, labor, and capital also gives more opportunities to earn income from other sources than cocoa. A small total income can be both a cause and a consequence of a lack of alternative sources of income because often some form of capital is required to engage in more lucrative income generating activities (Alobo Loison, 2015). On the other hand, when income from cocoa is high, there is less need for other sources of income to earn a high total household income. Unfortunately, the calculation of income of smallholder cocoa producers, and of their dependence on different income streams, is not straightforward. No formal pay checks are available, income is often generated by several household members and may come from many different on and off-farm sources, and some income is received in-kind, for instance in the form of food, rather than money (Tyszler et al., 2018c).

Cocoa yields on smallholder farms in West Africa remain stagnant around $400 \mathrm{~kg} / \mathrm{ha} / \mathrm{yr}$ (Van Vliet and Giller, 2017). Theoretical studies suggest the crop could produce 10 times as much under the West African climate if all nutrient constraints were removed and pests and diseases controlled (Zuidema et al., 2005). Given the importance of cocoa to smallholder 
livelihoods, its continued poor productivity also represents a poverty trap (cf. Tittonell and Giller, 2013), emphasizing the need to increase cocoa yields. Vanlauwe et al. (2014) highlight the need to enhance agricultural productivity in sub-Saharan Africa through sustainable intensification, buffering farmers against shocks and paying attention to restricting expansion of the area under agriculture to maintain other ecosystem services. Sustainable intensification of smallholder cocoa production through optimizing management practices is certainly feasible: yields of up to $3,000 \mathrm{~kg} / \mathrm{ha}$ have been reported on some smallholders' farms in Ghana, with an average yield of about $1,225 \mathrm{~kg} / \mathrm{ha}$ (Mondelēz International, 2019). Aneani and OforiFrimpong (2013) estimate that on-farm yields of $1,875 \mathrm{~kg} / \mathrm{ha}$ are plausible in Ghana based on the maximum farmers' yields found in a previous study, and Abdulai et al. (2020) recorded farmers' yields of $2,125 \mathrm{~kg} / \mathrm{ha}$.

Despite the widespread attention, information on the current status of poverty and the income of smallholder cocoa producers remains limited to a small number of sources. In this article we address two main questions. First, we assembled all the different datasets from household surveys we could access, and used them to calculate the income of cocoa producing households in Ghana and Côte d'Ivoire, to address the question as to whether they would lead to similar conclusions to be drawn on the incidence of poverty and income. We compare these incomes with the World Bank extreme poverty line and the Living Income benchmarks of both countries. To understand the differences between the outcomes, we investigated the variables underlying income per person per day such as household size, cocoa yield, farm size, and income from sources other than cocoa.

Second, increases in yield (e.g., World Cocoa Foundation, 2017; Cargill, 2019; Mondelēz International, 2019) and/or increases in cocoa prices received by producers (e.g., Fountain and Hütz-Adams, 2018; Solidaridad, 2020a; Tony's Chocolonely, 2020) are frequently proposed as options to improve the income of cocoa producing households. Given our interest in the sustainable intensification of cocoa production, we used the most comprehensive dataset available to explore the question as to what are the relative impacts of raising the price that farmers are paid for their cocoa compared with the effect of increasing cocoa yields on the incidence of poverty and income.

\section{METHODS}

\section{Datasets Used}

Several data sets from household surveys concerning smallholder cocoa production in Côte d'Ivoire and Ghana were compared (Table 1). The household surveys were conducted for different reasons using different questionnaires and different sampling strategies.

In terms of data cleaning, apart from cocoa yields we did not set any definition of "outliers." Although some values seemed unlikely we had no firm basis to exclude data as we were unable to check the validity of values with the interviewees. An exception is yield. Yields exceeding 2,000 kg/ha are rare, but possible. However, it is virtually impossible for cocoa yields in West Africa to exceed 5,000 kg/ha (Van Vliet and Giller, 2017). Hence, all data of variables related to yields above this threshold were excluded (i.e., yield, cocoa land size, cocoa production, and income). This was only the case in the Cargill data set, and applied to $<0.1 \%$ of the respondents. In some data sets, zero values were excluded from the analyses because they seemed to represent missing data. In other data sets, the nature of the calculation of some variables led to exclusion of zero values. For consistency, zero values in variables regarding cocoa land and production were excluded from all data sets. This means that only producers which had (access to) cocoa land and cocoa production, and therefore cocoa income in the year of study, were included. Zero values of household size were also excluded. Outliers (defined as values deviating four standard deviations or more from the mean per country) for a number of numeric variables (e.g., land size, cocoa production, cocoa yield, number of household members) were removed from the KIT data set prior to publication of the data (Tyszler et al., 2018c). We used the data set from KIT for the analysis of relations between variables and for the scenarios, as this survey is the most complete, recent, and has the most random sample of cocoa producers of the different surveys available.

Variables explored were income, cocoa yield, cocoa area, and total farm area. Pearson correlation analyses were conducted to assess the relationship between total gross income per household member per day and several relevant variables. All calculations, analyses, and graphs were done using R 3.5 (R Core Team, 2018).

\section{Gross and Net Income (\$ PPP 2018 per Person per day)}

Income was expressed in \$ PPP 2018 per person per day (pppd). All income sources for each household were grouped into either "Cocoa income" (gross cocoa income, as it was not possible to calculate net income for all the data sets), "Other on-farm income" (income from other crops than cocoa, and livestock), and "Off-farm income" (all other sources of income, e.g., off farm employment). Income from sources other than cocoa were not available in the Cargill data set. Gross cocoa income was calculated based on total cocoa production of the household and the cocoa price of the year of data collection (Table 2) rather than using respondents' estimates of cocoa income.

For the KIT database, where more detailed information on expenditure was available, net income from cocoa was calculated. Income from other sources was based on respondents' estimates. Note that cocoa prices, expressed in \$ PPP 2018, may differ by as much as a third between years, though this difference would have been much larger when comparing the cocoa prices in local currency without taking into account inflation and purchasing power per year and country. Household income was then divided by the number of household members and by 365 to arrive at gross income per person per day. Income in local currency (CFA or GHФ) was converted from its value in the year of collection to its value in 2018 using Consumer Price Indices (World Bank, 2019). Finally, all income data was converted from local currency (2018) to \$ PPP 2018 using PPP conversion factors (World Bank, 2019). 
TABLE 1 | Data sets of cocoa-producing households surveyed in Côte d'Ivoire (CDI) and Ghana.

\begin{tabular}{|c|c|c|c|c|c|c|c|c|c|}
\hline Data set & $\begin{array}{l}\text { Objective of the } \\
\text { study }\end{array}$ & & Geographic locations & Sampling method & For our research & Income & Land availability & $\begin{array}{l}\text { Household } \\
\text { members }\end{array}$ & Yield \\
\hline \multirow[t]{2}{*}{ KIT } & $\begin{array}{l}\text { To conduct a } \\
\text { major household } \\
\text { study in cocoa } \\
\text { growing regions to } \\
\text { better understand } \\
\text { the relative } \\
\text { importance of } \\
\text { cocoa in } \\
\text { comparison to } \\
\text { other crops, the } \\
\text { livelihood status of } \\
\text { different } \\
\text { households, and } \\
\text { intra-household } \\
\text { dynamics and } \\
\text { make these data } \\
\text { freely available }\end{array}$ & Ghana & $\begin{array}{l}\text { Regions: Ashanti, Central, } \\
\text { Brong Ahafo, Western, and } \\
\text { Eastern }\end{array}$ & $\begin{array}{l}\text { Random selection of } \\
\text { communities. } \\
\text { Households selected } \\
\text { using transect walks } \\
\text { in four directions per } \\
\text { village, all households } \\
\text { were eligible. } \\
\text { Minimum one third } \\
\text { female selected. } \\
\text { Respondents do not } \\
\text { need to be } \\
\text { household head }\end{array}$ & $\begin{array}{l}\text { Only households that } \\
\text { produced and sold } \\
\text { cocoa were selected }\end{array}$ & $\begin{array}{l}\text { Study calculates } \\
\text { gross cocoa income } \\
\text { by multiplying total } \\
\text { number of bags } \\
\text { produced per } \\
\text { household per year } \\
\text { with fixed price. We } \\
\text { recalculated total } \\
\text { cocoa production in } \\
\mathrm{kg} \text { for Ghana using a } \\
\text { weight per bag of } \\
62.5 \mathrm{~kg} \text { rather than } \\
64 \mathrm{~kg} \text {. }\end{array}$ & $\begin{array}{l}\text { Study provided data } \\
\text { on land used for } \\
\text { cocoa, all cultivated } \\
\text { land and all fallow } \\
\text { land. We calculated } \\
\text { total land (cultivated } \\
\text { + fallow) and land for } \\
\text { other crops } \\
\text { (cultivated-cocoa } \\
\text { land). }\end{array}$ & $\begin{array}{l}\text { Household consists } \\
\text { of all members that } \\
\text { live in the main } \\
\text { compound/house } \\
\text { and usually eat } \\
\text { together }\end{array}$ & $\begin{array}{l}\text { Yield is total } \\
\text { production divided } \\
\text { over total area per } \\
\text { household Mean } \pm \\
\text { SD threshold to } \\
\text { remove outliers. }\end{array}$ \\
\hline & & $\mathrm{CDI}$ & $\begin{array}{l}\text { Districts: Autonome de } \\
\text { Yamoussoukro, Lacs, } \\
\text { Montagnes, Bas-Sassandra, } \\
\text { Goh-Djiboua, Zanzan, } \\
\text { Sassandra-Marahoue, } \\
\text { Comoe, and Lagunes }\end{array}$ & & & & & & \\
\hline WUR & $\begin{array}{l}\text { To conduct a } \\
\text { baseline } \\
\text { assessment of six } \\
\text { cocoa projects } \\
\text { within a cocoa } \\
\text { programme } \\
\text { implemented in } \\
\text { Ghana, } \\
\text { Commissioned by } \\
\text { UTZ, Solidaridad } \\
\text { and IDH }\end{array}$ & Ghana & $\begin{array}{l}\text { Regions: Ashanti, Eastern, } \\
\text { and Western }\end{array}$ & $\begin{array}{l}\text { Random selection of } \\
\text { producers from six } \\
\text { project groups } \\
\text { working toward } \\
\text { certification and for } \\
\text { comparison from } \\
\text { three communities } \\
\text { that did not receive } \\
\text { any training related to } \\
\text { certification and were } \\
10 \mathrm{~km} \text { away from } \\
\text { project assisted } \\
\text { communities. } \\
\text { Farmers were later } \\
\text { stratified in different } \\
\text { stages of certification }\end{array}$ & $\begin{array}{l}\text { We did not } \\
\text { distinguish between } \\
\text { the project and } \\
\text { comparison groups }\end{array}$ & $\begin{array}{l}\text { We calculated gross } \\
\text { income from cocoa } \\
\text { by multiplying cocoa } \\
\text { production as } \\
\text { number of bags from } \\
\text { the three main plots } \\
\text { per farm times } 62.5 \\
\mathrm{~kg} / \mathrm{bag} \text { times the } \\
\text { cocoa price of } \\
2010 / 11 \text {. Only } 12 \% \\
\text { of farmers have more } \\
\text { than three cocoa } \\
\text { plots. Data on other } \\
\text { income were used as } \\
\text { reported. }\end{array}$ & $\begin{array}{l}\text { Only data on number } \\
\text { of plots and sizes of } \\
\text { the three largest } \\
\text { plots. No data on } \\
\text { other land use. }\end{array}$ & idem. & $\begin{array}{l}\text { idem but for the three } \\
\text { largest plots per } \\
\text { household. }\end{array}$ \\
\hline
\end{tabular}




\begin{tabular}{|c|c|c|c|c|c|c|c|c|c|}
\hline Data set & $\begin{array}{l}\text { Objective of the } \\
\text { study }\end{array}$ & & Geographic locations & Sampling method & For our research & Income & Land availability & $\begin{array}{l}\text { Household } \\
\text { members }\end{array}$ & Yield \\
\hline WUR & $\begin{array}{l}\text { To conduct a } \\
\text { baseline } \\
\text { assessment of } \\
\text { cocoa projects } \\
\text { within a cocoa } \\
\text { programme } \\
\text { implemented in } \\
\text { Cote D'Ivoire, } \\
\text { Commisioned by } \\
\text { UTZ, Solidaridad } \\
\text { and IDH }\end{array}$ & CDI & $\begin{array}{l}\text { Districts: Lacs, Montagnes, } \\
\text { Bas-Sassandra, Gôh-Djiboua, } \\
\text { Sassandra-Marahoué, } \\
\text { Comoé, Lagunes }\end{array}$ & $\begin{array}{l}\text { A stratified sample of } \\
\text { farmers was } \\
\text { selected, aiming to } \\
\text { be representative of } \\
\text { UTZ programme } \\
\text { cocoa farmers in } \\
\text { terms of membership } \\
\text { of coops with and } \\
\text { without linkages to } \\
\text { traders, coops at } \\
\text { different stages of } \\
\text { certifications and } \\
\text { training, coops } \\
\text { located in three } \\
\text { different } \\
\text { agro-ecological } \\
\text { zones, and farmers } \\
\text { not in the UTZ } \\
\text { programme } \\
\text { (comparison group). }\end{array}$ & $\begin{array}{l}\text { We used the full data } \\
\text { set without } \\
\text { distinguishing the } \\
\text { various groups. }\end{array}$ & $\begin{array}{l}\text { Gross income from all } \\
\text { plots based on } \\
\text { production and price. } \\
\text { Data on other income } \\
\text { were used as } \\
\text { reported. }\end{array}$ & $\begin{array}{l}\text { Number and size of } \\
\text { all cocoa plots per } \\
\text { household available. } \\
\text { Used to calculate } \\
\text { total coca cultivated } \\
\text { area }\end{array}$ & idem. & idem \\
\hline Cargill & $\begin{array}{l}\text { To measure } \\
\text { progress, } \\
\text { performance, and } \\
\text { cocoa production } \\
\text { of the farmers as } \\
\text { the core of the } \\
\text { monitoring and } \\
\text { evaluation system } \\
\text { of Cargill }\end{array}$ & CDI & $\begin{array}{l}\text { Autonome de Yamoussoukro, } \\
\text { Lacs, Montagnes, } \\
\text { Bas-Sassandra, Goh-Djiboua, } \\
\text { Zanzan, } \\
\text { Sassandra-Marahoue, } \\
\text { Comoe, and Lagunes. }\end{array}$ & $\begin{array}{l}\text { Farm and household } \\
\text { data collected by } \\
\text { coaches and cocoa } \\
\text { production data } \\
\text { collected by } \\
\text { cooperatives were } \\
\text { received for all } \\
\text { members from UTZ } \\
\text { certified cooperatives } \\
\text { that all received } \\
\text { personal coaching. } \\
\text { Only } 5 \% \text { of the } \\
\text { farmers in the dataset } \\
\text { were not yet certified. }\end{array}$ & $\begin{array}{l}\text { We merged the } \\
\text { datasets and used } \\
\text { the data of all farmers } \\
\text { for the years } \\
2017-2018\end{array}$ & $\begin{array}{l}\text { Gross cocoa income } \\
\text { based on production } \\
\text { multiplied by price of } \\
2017 / 18 \text { plus } \\
\text { premium of } 35 \\
\text { CFA } / \mathrm{kg}\end{array}$ & $\begin{array}{l}\text { Data on cocoa } \\
\text { cultivated land, forest } \\
\text { and fallow but not on } \\
\text { other crops. Total } \\
\text { area per household } \\
\text { could not be } \\
\text { calculated. }\end{array}$ & $\begin{array}{l}\text { Number of people } \\
\text { reported to be under } \\
\text { the care of the cocoa } \\
\text { farmer plus one } \\
\text { (respondent). }\end{array}$ & idem \\
\hline $\begin{array}{l}\text { Ghent } \\
\text { Univ. /Univ. } \\
\text { of Ghana }\end{array}$ & $\begin{array}{l}\text { To analyse the } \\
\text { determinants of } \\
\text { cocoa productivity } \\
\text { and profitability by } \\
\text { smallholder } \\
\text { farmers in Ghana } \\
\text { to provide insights } \\
\text { into challenges for } \\
\text { future cocoa } \\
\text { farming, to guide } \\
\text { the formulation } \\
\text { and prioritization } \\
\text { of tailored policies }\end{array}$ & Ghana & $\begin{array}{l}\text { Regions: Ashanti, Brong } \\
\text { Ahafo, Central, Eastern, Volta, } \\
\text { and Western }\end{array}$ & $\begin{array}{l}\text { In each region, five } \\
\text { cocoa growing } \\
\text { districts were } \\
\text { randomly selected } \\
\text { except for Central (all } \\
\text { 4) and Volta (all 2). In } \\
\text { each district two } \\
\text { communities were } \\
\text { randomly selected } \\
\text { from which cocoa } \\
\text { producer were } \\
\text { selected by extension } \\
\text { workers. }\end{array}$ & $\begin{array}{l}\text { We used all available } \\
\text { data }\end{array}$ & $\begin{array}{l}\text { Cocoa production } \\
\text { was recalculated } \\
\text { using a weight per } \\
\text { bag of } 62.5 \mathrm{~kg} \text { rather } \\
\text { than } 64 \mathrm{~kg} \text {. Gross } \\
\text { cocoa income } \\
\text { calculated by } \\
\text { multiplying kg } \\
\text { produced with a fixed } \\
\text { price. Data on total } \\
\text { gross income were } \\
\text { used as reported }\end{array}$ & $\begin{array}{l}\text { Number and size of } \\
\text { each cocoa field were } \\
\text { reported from which } \\
\text { we calculated total } \\
\text { cocoa cultivated land } \\
\text { per household. Study } \\
\text { provided no } \\
\text { information on other } \\
\text { land uses. }\end{array}$ & $\begin{array}{l}\text { Total household size } \\
\text { was the sum of } \\
\text { number of husbands } \\
\text { or wives, sons and } \\
\text { daughters and other } \\
\text { dependents plus one } \\
\text { (respondent) }\end{array}$ & $\begin{array}{l}\text { Yield calculated as } \\
\text { cocoa production for } \\
\text { year 2013/14 divided } \\
\text { by cocoa area per } \\
\text { household }\end{array}$ \\
\hline
\end{tabular}


TABLE 2 | Standardization of cocoa prices per kg to \$ purchasing power parity (\$ PPP 2018).

\begin{tabular}{|c|c|c|c|c|c|}
\hline Study & Country & Data year & Local currency ${ }^{\mathrm{a}}$ in data year & Local currency calculated to 2018 & \$ PPP 2018 \\
\hline WUR & Ghana & $2011 / 2012$ & 3.20 & 7.51 & 4.53 \\
\hline WUR & Côte d'Ivoire & $2011 / 2012$ & 725 & 770 & 3.39 \\
\hline Ghent University & Ghana & $2013 / 2014$ & 3.39 & 5.76 & 3.48 \\
\hline KIT & Côte d'Ivoire & $2015 / 2016$ & 1000 & 1011 & 4.45 \\
\hline KIT & Ghana & $2015 / 2016$ & 6.80 & 8.39 & 5.07 \\
\hline Cargill & Côte d'Ivoire & $2017 / 2018$ & $735^{\mathrm{b}}$ & 735 & 3.23 \\
\hline
\end{tabular}

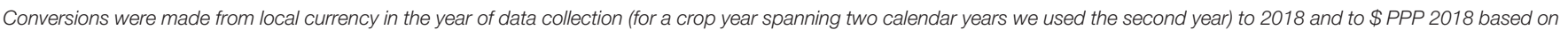
World Bank (2019) conversion factors.

${ }^{a} \mathrm{GHC}$ for Ghana and CFA for Côte d'Ivoire.

${ }^{b}$ This includes a cash premium of 35 CFA/kg of cocoa.

\section{Cocoa Yield}

Average yields (kg of fermented dry beans) per household were calculated as total household cocoa production divided by total area of cocoa per household. This included area which had been (re)planted recently and was not yet in production, which may be up to $24 \%$ of the land under cocoa (based on the KIT data for Ghana). The yield of the total cocoa area is thus an underestimation of the yield on productive cocoa land. Note that the cocoa area may include land which is cropped but not owned by the respondent.

\section{Income Benchmarks}

We compared the calculated incomes per person per day against two benchmarks: the World Bank international extreme poverty line and the Living Income benchmarks of Ghana and Côte d'Ivoire according to the Living Income Community of Practice. The World Bank international extreme poverty line is set at 1.90 \$ PPP (2011) per person per day (Ferreira et al., 2016), which equals 2.12 \$ PPP (2018) (World Bank, 2019). Since 2017, the World Bank also reports a poverty line of 3.20 \$ (PPP 2011) per capita per day for lower-middle-income countries such as Ghana and Côte d'Ivoire besides the extreme poverty line (World Bank, 2018). Nevertheless, we use the 1.90 (PPP 2011; which is $2.12 \$$ PPP 2018) line as this remains the most widely used as an income benchmark (e.g., Barry Callebaut, 2018).

The Living Income benchmark for Ghana was established by Smith and Sarpong (2018) for rural cocoa producing areas in Ashanti, Central, Eastern, and Western Regions. It was set at GH\$1,464 per month for a typical reference family of two adults and three children. We recalculated this to $\mathrm{GH} \not$ per person (divide by 5) per day (multiply by 12 months, divide by 365 days). Then we recalculated to \$ PPP (2018) using the GH\&PPP conversion factor for 2018 (World Bank, 2019). This comes to 5.81 \$ PPP (2018) per person per day. The Living Income benchmark for Côte d'Ivoire was established by CIRES (2018) for rural cocoa growing areas. It was set at CFA 262,056 per month for a typical reference family of two adults and four children. This was recalculated as described above for Ghana to give 6.32 \$ PPP (2018) per person per day. As the annual Living Income benchmark is often calculated on the basis of a typical reference household, we converted to per person per day using the number of household members of the reference household to allow comparison of households of different size. Tyszler et al. (2018a,b) chose to differentiate by using three contrasting reference households to establish different Living Income benchmarks and then compared each household to the most similar reference household. Van De Ven et al. (2020) recommend standardization of incomes using equivalence scales to account for the varying needs of household members in terms of food and income. Insufficient information was available from all of the surveys to allow this, but we conducted an exercise with the KIT data to explore the effect of using the adult equivalent (AE) for income (see Supplementary Figure 1).

\section{Scenarios}

We explored the effect of increasing the price paid to farmers for their cocoa and the effect of increasing cocoa yield on the proportion of cocoa producers who fall below the poverty line of the Living Income threshold, using the KIT survey data. Increasing cocoa price and increasing cocoa yield are the two most often mentioned options to increase income.

The effect of increasing the price was explored in two ways: first by imposing the Living Income Differential of 400 USD per ton recently agreed by the governments of Côte d'Ivoire and Ghana (Reuters, 2019); and second by doubling the cocoa price compared to that of 2015/2016. The first was based on the conversion of the minimum farm gate price for 2020/2021 resulting from the Living Income Differential ( 1,820 USD/ton) to local currency and then to PPP 2018, which comes to cocoa farm gate prices of $5.04 \$ \mathrm{PPP} / \mathrm{kg}$ in Ghana and $4.45 \$ \mathrm{PPP} / \mathrm{kg}$ in Côte d'Ivoire. The latter is close to the minimum price proposed by Fountain and Hütz-Adams (2019) following a similar method of calculation, which according to them is required for cocoa producers to earn a Living Income.

The effect of increasing cocoa yield was explored by increasing yields of all households to $1,500 \mathrm{~kg} / \mathrm{ha}$. Although few producers currently achieve such yields, it is certainly possible to reach 1,500 $\mathrm{kg} / \mathrm{ha}$ or more on farmers' fields using what can be considered to be best management practices (i.e., pruning, crop protection methods, and fertilizer use) (Aneani and Ofori-Frimpong, 2013; Mondelēz International, 2019; Abdulai et al., 2020). Additionally, we tested the effects of increasing farmers' cocoa yields more modestly to 600,800 and $1,000 \mathrm{~kg} / \mathrm{ha}$. In the scenarios, we assumed no change in non-cocoa income. Increased investment 
in inputs (of labor, fertilizer, and plant protection agents) is needed to increase yields. We therefore tested the effect of increasing yields to $1,500 \mathrm{~kg} / \mathrm{ha}$ while subtracting $30 \%$ of the cocoa income as the investment costs (inputs plus labor) required to boost production, which is a generous allowance compared with what farmers invest currently in inputs and labor (Smith and Sarpong, 2018).

\section{RESULTS}

\section{Differences in Household Income Among the Surveys}

The incomes of many cocoa producing households in both Ghana and Côte d'Ivoire fell below the World Bank extreme poverty line of 2.12 \$ (PPP 2018), and the majority were below the Living Income benchmark of 5.81 \$ (PPP 2018) for Ghana and 6.32 \$ (PPP2018) for Côte d' Ivoire (Figure 2). There were also households whose income was well-above the Living Income benchmark, but these were rare in all data sets.

Although the overall patterns found are the same with all data sets, there were notable differences among countries and data sets (Table 3). The number of reported household members was larger in Côte d'Ivoire than in Ghana, and largest in the WUR study of Côte d'Ivoire. Although cocoa land area was generally somewhat smaller in Ghana, this area was divided over a larger number of plots than in Côte d'Ivoire. Mean and median yields were especially high in the Cargill study (Côte d'Ivoire) and lowest in the study of Ghent University (Ghana). Despite the low cocoa price (Table 2 ) and the relatively small cocoa land area, this leads to the highest mean and median income from cocoa per household member per day (pppd) in the Cargill study. The lowest mean and median income from cocoa pppd was obtained in the study of Ghent University. Mean and median total income pppd (not available for the Cargill study) was highest in the KIT study of Ghana. This was the consequence of high mean and median cocoa income pppd due to a high cocoa price (Table 2) and yields in combination with a larger amount of income from other sources. The lowest mean and median total income pppd was found in the WUR study of Ghana, resulting from a low cocoa income due to low yields and little income from other sources. In both countries, mean and median income from other sources pppd was highest for the KIT studies and lowest for the WUR studies. For further details see Table 1.

\section{Relationships Between Income and Other Variables}

The relationships between gross total income per person per day and a number of other variables were explored using the data from KIT (Figure 3).

There was a significant negative correlation between number of household members and income pppd (Figures 3A,B). The relation was stronger in Ghana $(r=-0.36, p<0.01)$, where of the households with income below the extreme poverty line, $73 \%$ had a household size larger than the population mean. This is $43 \%$ of those above the extreme poverty line. In Côte d'Ivoire, the relation was weaker $(r=-0.22, p<$
0.01 ) and of the households whose income was below the extreme poverty line, $56 \%$ were larger than the population mean while this was $39 \%$ for those above the extreme poverty line. On the other hand, the correlation between number of household members and total household income was positive, with a much stronger correlation in Côte d'Ivoire than in Ghana (Supplementary Table 1). In both countries, the spread of total income among more family members overrides the potential higher income earning capacity with more family members. There were relatively more dependents in larger families and a negative correlation between dependency ratio and income pppd (Supplementary Tables 1, 2). There was a significant positive correlation between total available land (ha) and income pppd (Figures 3C,D). The relation was stronger in Ghana, where 79\% of the households with income below the extreme poverty line had less land available than the population mean, while this was $56 \%$ of those above the extreme poverty line. In Côte d'Ivoire these percentages were $71 \%$ against $51 \%$. When fallow land was excluded, the correlation remained almost the same in Ghana but was much stronger in Côte d'Ivoire (Supplementary Table 1).

There was a significant positive correlation between cocoa yield and income pppd (Figures 3E,F). More than $70 \%$ of the households which had an income pppd below the extreme poverty line had cocoa yields of $<250 \mathrm{~kg} / \mathrm{ha}$ in both countries, while only around $30 \%$ of the rest of the population had such poor yields.

There was a significant negative correlation between the proportion of income derived from cocoa sales, and income pppd (Figures 3G,H). The more dependent a household was on income from cocoa, the lower their total income pppd. In Côte d'Ivoire, of the households with an income below the extreme poverty line, more than $66 \%$ depended more on cocoa than the population mean, while this was $49 \%$ for those above the extreme poverty line. In Ghana this was $58 \%$ against $40 \%$.

Note that the correlations of most variables with total household income are stronger than those with total income pppd (Supplementary Table 1) as income pppd is the combined result of total household income and number of household members. However, the income variable of interest is that per person, as household income does not reflect whether the needs of all household members can be met.

\section{Exploring the Potential Effects of Increasing Cocoa Prices or Increasing Yields}

We explored the impact of increasing the price paid to farmers for their cocoa in two ways. First, we changed the price paid to farmers according to the Living Income Differential for 2020/2021. In 2019, the governments of Côte d'Ivoire and Ghana applied a premium, known as the Living Income Differential, on the export price of cocoa for the 2020/2021 season of USD 400 per ton. This leads to a producer price increase compared with 2019/2020 of 1\% in Ghana and 23\% in Côte d'Ivoire, but virtually the same prices in \$ PPP 2018 as in 2015/2016, and therefore virtually no effect on income per person per day compared with the baseline scenario (Table 4). Second, we doubled the cocoa 


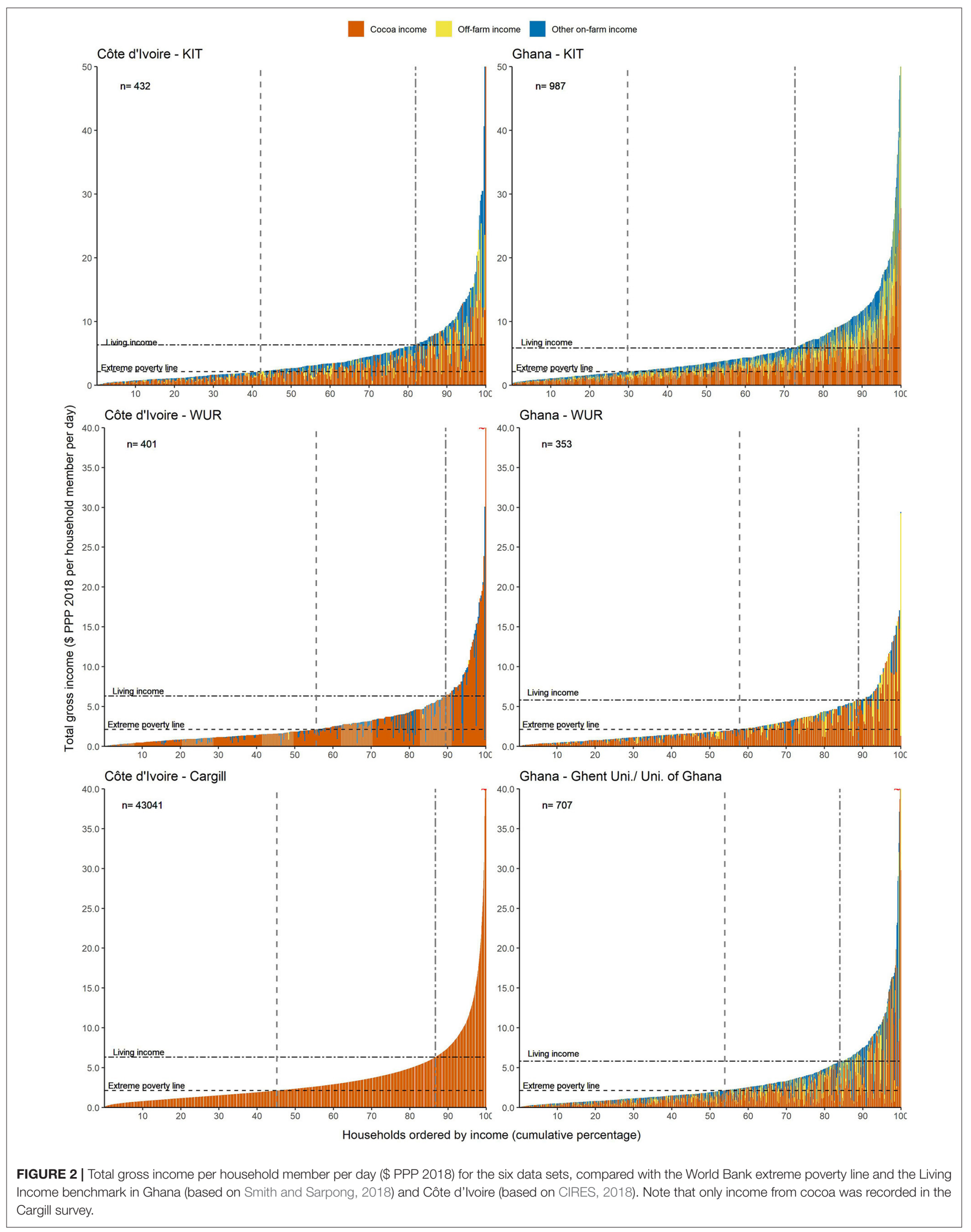


TABLE 3 | Summary of important variables calculated for each of the household survey data sets from Côte d'Ivoire and Ghana.

\begin{tabular}{|c|c|c|c|c|c|c|c|}
\hline & & \multicolumn{3}{|c|}{ Côte d'Ivoire } & \multicolumn{3}{|c|}{ Ghana } \\
\hline & & Cargill & WUR & KIT & WUR & KIT & Ghent University \\
\hline Number of observations used & & 88,896 & 426 & 992 & 385 & 1,384 & 731 \\
\hline Gender of the respondent ( $\%$ male $)^{a}$ & & 94 & 97 & 73 & 81 & 67 & 77 \\
\hline \multirow[t]{3}{*}{ Household members (\#) } & Mean & 7.45 & $8.86^{\mathrm{b}}$ & 6.99 & 6.04 & 5.86 & 6.46 \\
\hline & Median & 7 & 8 & 6 & 6 & 6 & 6 \\
\hline & Range & $1-51$ & $1-30$ & $1-21$ & $1-18$ & $1-16$ & $1-18$ \\
\hline \multirow[t]{3}{*}{ Cocoa yield $(\mathrm{kg} / \mathrm{ha})^{\mathrm{c}}$} & Mean & 587 & 435 & 295 & $275^{d}$ & 310 & 261 \\
\hline & Median & 565 & 376 & 263 & 205 & 270 & 208 \\
\hline & Range & $4-4,995$ & $5-2,233$ & $12-1,075$ & $3-1,544$ & $4-1,287$ & $2-1,562$ \\
\hline \multirow[t]{3}{*}{ Cocoa land area (ha) } & Mean & 4.0 & 5.2 & 4.2 & 4.2 & 3.6 & 4.4 \\
\hline & Median & 3.0 & 4.0 & 3.5 & 3.0 & 2.8 & 3.2 \\
\hline & Range & $0.1-93.4$ & $0.5-37.0$ & $0.25-16.0$ & $0.4-46.5$ & $0.35-13.8$ & $0.2-38.4$ \\
\hline \multirow[t]{3}{*}{ Total land area (ha) } & Mean & n.a. & n.a. & 9.0 & n.a. & 5.4 & n.a. \\
\hline & Median & & & 7.5 & & 4.25 & \\
\hline & Range & & & $0.5-35.0$ & & $0.35-24.3$ & \\
\hline \multirow[t]{3}{*}{ Number of cocoa plots (\#) } & Mean & 1.10 & 1.17 & n.a. & 2.16 & n.a. & 2.35 \\
\hline & Median & 1 & 1 & & 2 & & 2 \\
\hline & Range & $1-10$ & $1-5$ & & $1-7$ & & $1-8$ \\
\hline \multirow[t]{3}{*}{ Gross cocoa income pppd (PPP 2018) } & Mean & 3.73 & 2.76 & 2.68 & $2.20^{d}$ & 3.10 & 2.13 \\
\hline & Median & 2.34 & 1.55 & 1.61 & 1.40 & 2.02 & 1.07 \\
\hline & Range & $0.04-167.88$ & $0.01-58.83$ & $0.04-60.96$ & $0.03-16.30$ & $0.02-34.71$ & $0.02-44.67$ \\
\hline \multirow[t]{3}{*}{ Gross total income pppd (PPP 2018) } & Mean & n.a. & 3.19 & 4.48 & 2.86 & 5.44 & 3.43 \\
\hline & Median & & 1.86 & 2.67 & 1.81 & 3.47 & 1.90 \\
\hline & Range & & $0.01-58.83$ & $0.04-76.20$ & $0.03-29.42$ & $0.05-69.42$ & $0.05-45.44$ \\
\hline \multirow[t]{3}{*}{ Percentage income from cocoa (\%) } & Mean & n.a. & 89 & 67 & 82 & 62 & 65 \\
\hline & Median & & 100 & 70 & 91 & 60 & 70 \\
\hline & Range & & $3-100$ & $5-100$ & $1-100$ & $5-100$ & $2-100$ \\
\hline Poverty line (\% of households below) & & 45 & 56 & 42 & 58 & 30 & 54 \\
\hline Living income benchmark (\% of households below) & & 87 & 90 & 82 & 89 & 73 & 84 \\
\hline
\end{tabular}

${ }^{a}$ The respondents of the surveys were not necessarily the household heads.

b Number of household members was taken from the endline data set, as this survey used a more narrow definition of "household".

${ }^{c}$ Records with yields above $5,000 \mathrm{~kg} / \mathrm{ha}$ were excluded.

${ }^{d}$ This is the area, yield and income of the three main plots of the farmer. Some farmers may have more than three plots.

price compared with the prices of 2015/2016, which is virtually the same as doubling the price compared with that of 2019/2020 (Figure 4). In this case the percentage of households with gross incomes pppd below the extreme poverty line would be reduced from 42 to $25 \%$ in Côte d'Ivoire and from 30 to 15\% in Ghana. The percentage of households with incomes below the Living Income benchmark would fall from 82 to $65 \%$ in Côte d'Ivoire and from 73 to $53 \%$ in Ghana.

We also explored the effect of increasing yields on gross income per household member (Figure 5). If producers would reach a cocoa yield of $1,500 \mathrm{~kg} / \mathrm{ha}$ across their cocoa plantations, the percentage of households with incomes below the poverty line would be reduced from 42 to $2 \%$ in Côte d'Ivoire and from 30 to $<1 \%$ in Ghana. The percentage of households with gross incomes below the Living Income benchmark would fall from 82 to $20 \%$ in Côte d'Ivoire and from 73 to $13 \%$ in Ghana. Cocoa farmers would need to invest more to achieve these increases in yields, yet if $30 \%$ of the increase in income was allocated to the input costs, the impacts on reducing the proportion of farmers below the poverty of Living Income benchmarks would also be strong (Table 4). If yields would increase more modestly the percentages of households with gross incomes below the poverty line are still reduced strongly compared with the baseline scenario or the scenarios where prices are increased (Table 4). The same holds true for households with gross incomes below the Living Income benchmark. When all else remains equal, yield increases thus have a larger effect on decreasing income gaps than price increases, especially for the poorest households.

\section{DISCUSSION}

\section{Patterns of Poverty}

Regardless of the survey methods used, the patterns of outcomes were similar (Figure 2). Overall, our findings converge to the conclusion that more than $40 \%$ of cocoa producing households in Côte d'Ivoire and 30\% in Ghana fall below the World Bank 

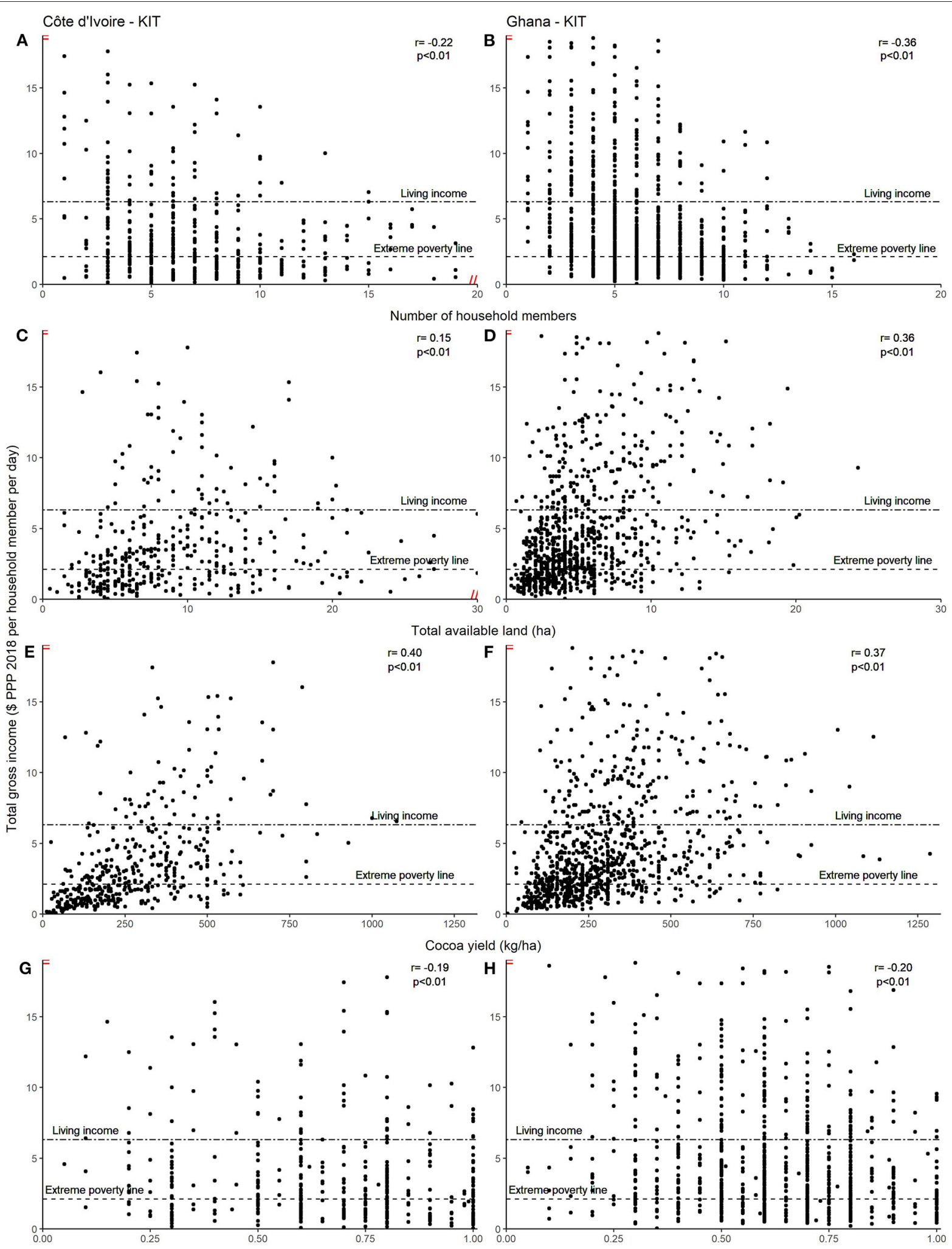

Cocoa yield (kg/ha)

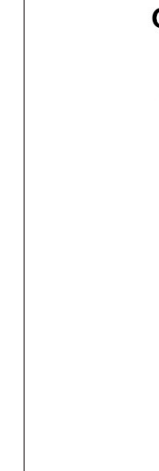

FIGURE 3 | Scatter plots of number of household members (A,B), total available land (ha; C,D), cocoa yield (kg/ha; E,F), and proportion of total income coming from cocoa sales $\mathbf{( G , H ) ~ o v e r ~ t o t a l ~ g r o s s ~ i n c o m e ~ p e r ~ h o u s e h o l d ~ m e m b e r ~ p e r ~ d a y ~ b a s e d ~ o n ~ d a t a ~ f r o m ~ K I T . ~ r - v a l u e s ~ a r e ~ P e a r s o n ~ c o r r e l a t i o n s ~ f o r ~ e a c h ~ v a r i a b l e ~ w i t h ~ i n c o m e ~}$ pppd. 


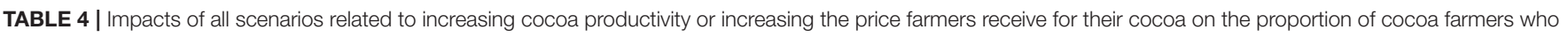
achieve an income equivalent to the World Bank extreme poverty line or the Living Income benchmark for Ghana of Smith and Sarpong (2018) and for Côte d'Ivoire of CIRES (2018).

\begin{tabular}{|c|c|c|c|c|}
\hline \multirow[b]{3}{*}{ Scenario } & \multicolumn{2}{|c|}{ Ghana } & \multicolumn{2}{|c|}{ Côte d'Ivoire } \\
\hline & \multicolumn{4}{|c|}{$\%$ of households with income below the } \\
\hline & Poverty line & Living income & Poverty line & Living income \\
\hline Baseline gross income & 29.8 & 72.7 & 42.1 & 81.9 \\
\hline Baseline net income & 32.0 & 73.3 & 44.3 & 82.5 \\
\hline Living Income Differential & 29.9 & 72.7 & 42.1 & 81.9 \\
\hline Double cocoa price & 14.8 & 52.6 & 25.0 & 65.0 \\
\hline Cocoa yield of $600 \mathrm{~kg} / \mathrm{ha}$ & 7.1 & 48.4 & 10.6 & 61.8 \\
\hline Cocoa yield of $800 \mathrm{~kg} / \mathrm{ha}$ & 3.3 & 35.4 & 8.6 & 46.3 \\
\hline Cocoa yield of $1,000 \mathrm{~kg} / \mathrm{ha}$ & 1.9 & 26.8 & 4.4 & 35.9 \\
\hline Cocoa yield of $1,500 \mathrm{~kg} / \mathrm{ha}$ & 0.6 & 13.3 & 1.6 & 20.1 \\
\hline Cocoa yield of $1,500 \mathrm{~kg} / \mathrm{ha}$, deducting $30 \%$ of cocoa income due to increased cost of production & 1.6 & 24.5 & 3.5 & 31.9 \\
\hline
\end{tabular}

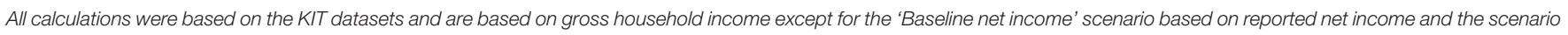
where $30 \%$ of income are allowed for increased costs of production to raise yields to 1,500 kg/ha.

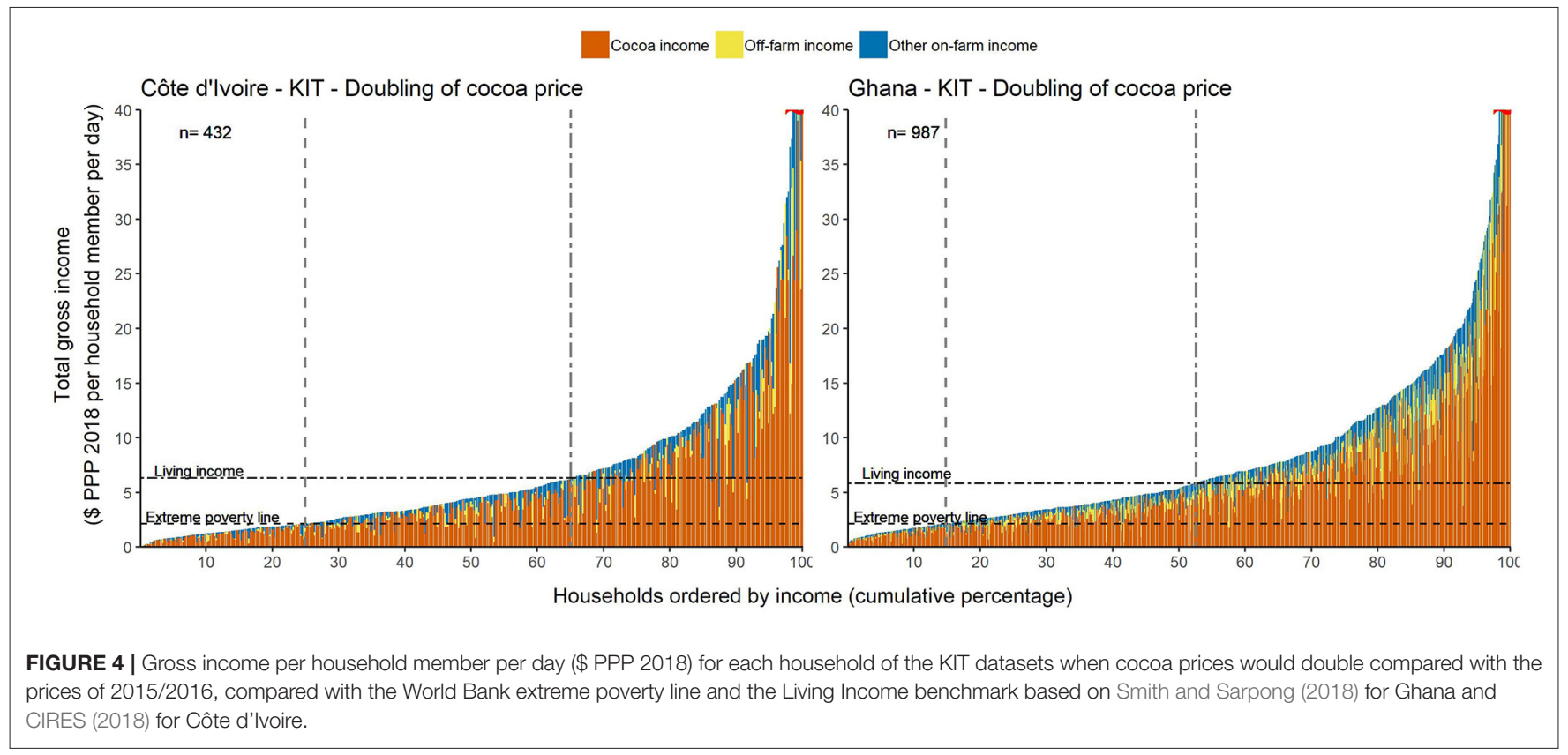

extreme poverty line, with the highest percentages found in the WUR studies (58\% in Ghana and 56\% in Côte d'Ivoire). The vast majority of cocoa producing households fall below the Living Income benchmark: between $73 \%$ in Ghana (KIT) and $90 \%$ in Côte d'Ivoire (WUR). These outcomes reflect the findings of other studies, yet the exact figures are difficult to compare. For instance, the World Cocoa Foundation estimates that more than two-thirds of cocoa producers in some West African countries live below the poverty line (World Cocoa Foundation, 2020). This is higher than we find in any of the data sets studied, where we find percentages of household below the poverty line ranging from 30 to $58 \%$ (Figure 2; Table 3). However, we cannot be certain that the World Cocoa Foundation used the same poverty threshold. Peprah (2019) reports on a yearly gross cocoa income of 2,528 \$ in Côte d'Ivoire, and 1,793 \$ in Ghana (no year indicated), which is about 2-3 times less that estimated from the KIT study when assuming purchasing power parity has not been taken into account, and taking into account inflation. Other sources refer to total incomes of 0.78 \$ pppd (Fountain and Hütz-Adams, 2018), 1.17 \$ pppd (Balineau et al., 2016), or $€ 0.46$ pppd (Tony's Chocolonely, 2020), which again seem to be less than what we found. However, it is difficult to compare these income estimates as they are expressed in different (and often poorly-defined) units, it is not always clear whether they are based on gross or net income, how the number of household members has been defined, and whether all sources of income are 


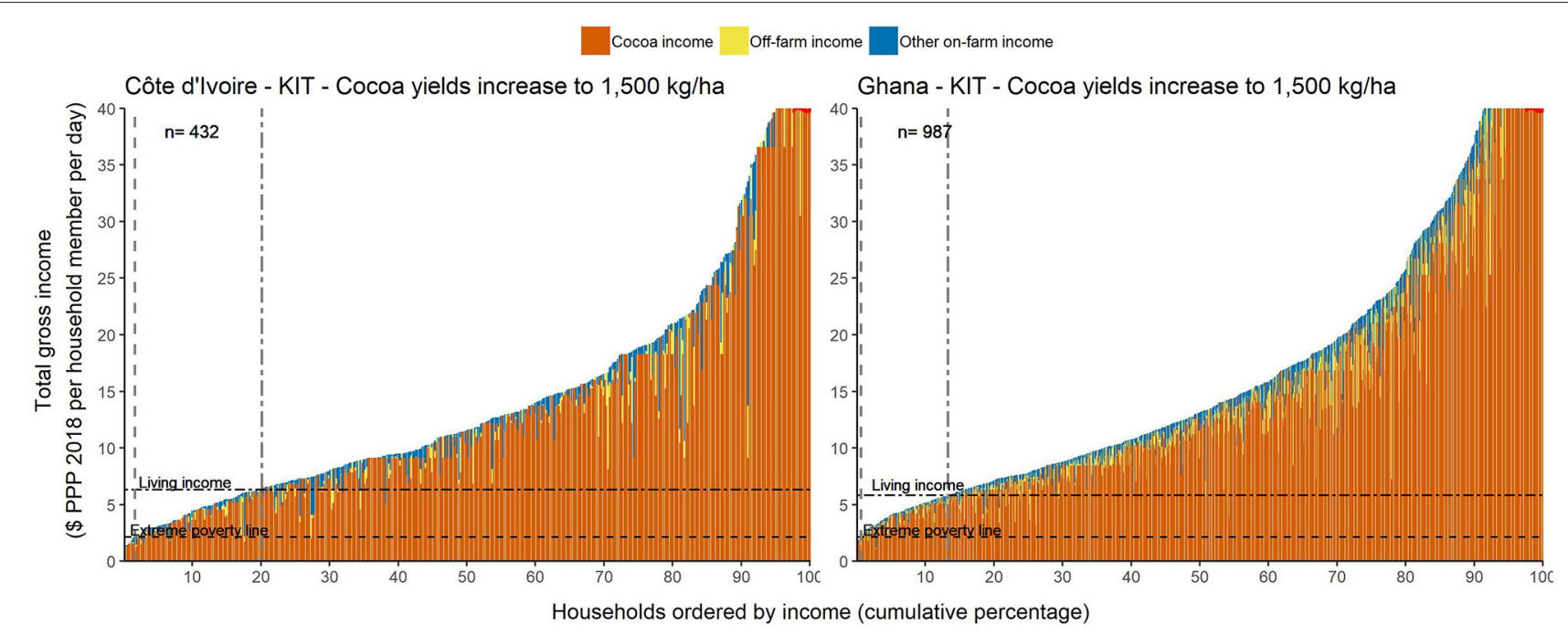

FIGURE 5 | Gross income per household member per day (\$ PPP 2018) for each household of the KIT datasets when cocoa yields would increase to 1,500 kg/ha at the cocoa prices of 2015/2016, compared with the World Bank extreme poverty line and the Living Income benchmark based on Smith and Sarpong (2018) for Ghana and CIRES (2018) for Côte d'Ivoire.

accounted for. Further, differences among surveys and reports may be due to several factors, in particular the sampling frame which often includes only the farmers within a specific region or supply chain, and the topics and questions employed in the surveys. It would be very useful if a standard measure could be established for reporting of income, using the same assumptions and methodology across different studies.

Interestingly, Peprah (2019) refers to the World Bank (2017) for information on cocoa producer income, which in turn refers to the website of the Cocoa Barometer (https://www. voicenetwork.eu/cocoa-barometer/). They refer to the Cocoa Barometer of 2015, which states that their estimates are based on "extensive literature study" (Fountain and Hütz-Adams, 2015). The Cocoa Barometer of 2018 (Fountain and Hütz-Adams, 2018) is largely based on income data from the KIT study (Tyszler et al., 2018c) and a study commissioned by FairTrade (True Price, 2018). Cargill (2019) also refers to the KIT study for their estimate of the share of total income derived from cocoa. Overall, there seem to be few independent studies published regarding the income of cocoa producers, all of which conclude that most cocoa producers do not earn a Living Income and/or many earn below the poverty line.

\section{Differences in Outcomes Among the Studies}

There were large differences in the income distributions among the studies (Figure 2), although the overall patterns were similar. Mean and median income from cocoa pppd in the Cargill data was higher than in any of the other studies due to very high yields (Table 3). This is likely, at least in part, to be because all respondents were members of cooperatives in the "Cargill Cocoa Promise" program (Table 1). These farmers receive individual coaching and trainings. Nearly all of them are UTZ certified and receive a cash premium of $35 \mathrm{CFA} / \mathrm{kg}$ cocoa (Table 1). The good yields are likely the result from a combination of increased knowledge on good agricultural practices, and stronger motivation to invest labor and capital into cocoa production. To a lesser degree, this is also the case for the WUR data set of Côte d'Ivoire. Here, most respondents were members of producer groups who participated in the UTZ certification program, but did not receive individual coaching. The lowest mean and median yields in Côte d'Ivoire were found in the KIT data. Here, the cocoa producers are randomly selected and only $21 \%$ of the households in Côte d'Ivoire were members of a producer group (Bymolt et al., 2018). The variation in mean and median yields was much smaller among the data sets from Ghana, than those from Côte d'Ivoire. This may be caused by adverse weather conditions in Ghana for the 2015/2016 season, the data year for KIT (Reuters, 2015, 2016).

Another variable which differed widely among the data sets was the households' income from sources other than cocoa (Table 3; Figure 2), although not all surveys included this. The mean and median percentage of income from other sources was much smaller in the WUR data than in other data sets, contributing to the low total income. This could, again, be related to the group sampled or different ways in which the questions regarding income sources were framed. Total land availability, important for considering diversification options, was only available in the KIT data sets (Table 3). An overall conclusion however, is that greater availability of land, especially under cultivation, leads to a larger total income (Figure 2), both from cocoa and from other crops.

We conclude that the differences in variables underlying total gross income per person per day are for a large part caused by different target populations included in the surveys and framing of questions, as well as differences in cocoa prices and weather 
conditions between years. Unfortunately, not all variables were available for all data sets, prohibiting some comparisons.

\section{Patterns in Farmer Incomes}

Cocoa production is the largest source of income (about twothirds or more in both countries, Table 3) for most households. Thus, as conceptualized in Figure 1, cocoa price, area and yield have a large effect on total income pppd (Figures 3E,F; Supplementary Material 1). In general the correlations among variables measured were fairly weak and should not be interpreted as indicative of causal relationships. The weak negative effect of cocoa area on cocoa yield ( $\mathrm{kg} / \mathrm{ha}$ ) (in Ghana but not in Côte d'Ivoire, Supplementary Material 1) is probably related to a lack of capital and labor to invest in maintaining high yields on a larger area of land. In Ghana, where most of the available land is under cultivation and can therefore contribute to cocoa and other crop production, the effect of total available land on total household income is strong (Figures 3C,D). In Côte d'Ivoire, this relation is much weaker as much of the total available land is left fallow (median: $1.5 \mathrm{ha}$, mean: 2.6 ha against median: 0 ha, mean: 0.6 ha in Ghana). It seems that in Côte d'Ivoire, more households face constraints such as shortage of labor and capital which restrict the proportion of land that they cultivate. The higher labor shortage in Côte d'Ivoire compared to Ghana is confirmed by Odijie (2016) and attributed to higher labor needs in replanted cocoa than in first cycle cocoa on prior forest land.

Because large households generally have more productive household members, there is a positive correlation of number of household members with total household income. However, as they generally consist of relatively more dependents the relationship with income pppd is negative (Figures 1, 3A,B). Household or family labor is the most prevalent source of labor for cocoa activities (Bymolt et al., 2018) as it is cheap and effective. Household labor can be supplemented or substituted when enough capital is available e.g., for hiring labor and/or applying herbicides (Van Vliet et al., 2015). In Ghana the relation between total household income and number of (productive) household members is much weaker than in Côte d'Ivoire. In Ghana, more use is made of hired labor and herbicides (Bymolt et al., 2018). As a result, household labor is less of a constraint to increasing household income than in Côte d'Ivoire.

Overall, the results of these analyses are consistent with the conceptual scheme presented in Figure 1, suggesting the importance of self-amplifying mechanisms. Households with a higher income are more likely to be able to afford to invest in production through accessing inputs and hiring labor, giving them access to a larger total labor force and therefore gain a higher income (Figure 1). By contrast, the low cocoa price, low cocoa yields, lack of income from other sources, low availability of land, and large households with relatively many dependents result in poverty traps for the poorer households (Figure 1).

\section{Options to Increase Income of Cocoa Producers}

Here, we focus on three determinants of household income which are prominent in the causal diagram (Figure 1): the cocoa producer price, cocoa yields, and other sources of income (diversification on or off the farm).

\section{Scenario 1: Increasing Cocoa Prices}

The Living Income Differential recently imposed by the governments of Côte d'Ivoire and Ghana leads to a producer price of 1,820 USD per ton. This is virtually the same as the producer prices in 2015/2016 when expressed in \$ PPP 2018, so when changing the prices of 2015/2016 to those resulting from the Living Income Differential for 2020/2021 there is little to no effect on farmer incomes (Table 4). We went on to explore the relative impact on different households of a more drastic scenario of doubling cocoa prices. Although this clearly represents a substantial increase, for comparison it is only $14 \%$ more than the minimum cocoa producer price of 3,000 US \$ per ton which the Voice Network deems necessary for cocoa producers to earn a Living Income (Fountain and Hütz-Adams, 2019). Such a price increase significantly improves the incomes of the already betteroff producers. They generally produce large volumes of cocoa due to large cocoa land area and/or good yields, and therefore a price increase would have a large impact on their income. For the poorest whose total cocoa production is limited due to small land areas and/or low yields the impact is much less visible. Of course, even a small increase in income would be of great value to the poorer households, but insufficient to provide a Living Income or raise them above the poverty line.

\section{Scenario 2: Increasing Cocoa Yields}

We explored a scenario in which all cocoa yields increase to $1,500 \mathrm{~kg} / \mathrm{ha}$, using the KIT survey data (Scenario 2). Although few producers currently achieve such yields, it is a fairly modest target compared with the crop's technical potential (Zuidema et al., 2005; Van Vliet and Giller, 2017). As explained in the introduction there are several examples where smallholders have achieved cocoa yields well above $1,500 \mathrm{~kg} / \mathrm{ha}$, although in the Cargill surveys, only $1.4 \%$ of 86,380 producers achieved yields of $1,500 \mathrm{~kg} / \mathrm{ha}$ or more. Yields generally achieved by farmers are around $300-400 \mathrm{~kg} / \mathrm{ha}$, except in the Cargill sample where mean yields are close to $600 \mathrm{~kg} / \mathrm{ha}$ (Table 3). It would be worthwhile to further investigate the factors underlying these relatively high yields.

Increasing cocoa yields to $1,500 \mathrm{~kg} / \mathrm{ha}$ leads to a large increase in gross income across households. Only $1-2 \%$ of households fall below the poverty line in this scenario, and only $14-20 \%$ remain below the Living Income benchmark (Table 4). The income benefits are largest for the poorer producers because they often have the lowest starting yields (Figures 2E,F); about $70 \%$ of those living below the poverty line have yields below $250 \mathrm{~kg} / \mathrm{ha}$. Therefore, for them the increase in income resulting from the yield increase is largest. We also calculated the effects of more modest yield increases to 600,800 , or $1000 \mathrm{~kg} / \mathrm{ha}$ (Table 4). Even an increase to only $600 \mathrm{~kg} / \mathrm{ha}$ has a stronger effect than doubling cocoa price on the proportion of households above the poverty line or those earning a Living Income. This further suggests that increasing income through yield intensification has larger benefits for the poorest farmers than increasing prices. 
However, the poorest producers also face the greatest challenges to increase their cocoa yields. Investment is needed to intensify production through increased management (e.g., pruning, weeding, frequent harvesting) and inputs (e.g., fertilizers, pesticides) and, in the longer term, perhaps even replanting (Aneani and Ofori-Frimpong, 2013; Kongor et al., 2018; Abdulai et al., 2020). All of these require resources such as capital and labor to which these producers often lack access (Figure 5, Fountain and Hütz-Adams, 2018, 2019). Although there is a positive correlation between expenditure on inputs and yields (Supplementary section S3), it is difficult to estimate the increase in expenditure required to increase yields to 1,500 $\mathrm{kg} / \mathrm{ha}$. Clearly, required investments per ha will be greatest for farmers with the lowest current yields, who are often the poorest (Figures 2E,F). Moreover, return on investments is unpredictable and producers may not be able to bridge the time between investments and benefits (Assiri et al., 2012; Ruf and Bini, 2012). We explored the effects of an extra scenario in which $30 \%$ of the income generated by increasing yields to $1,500 \mathrm{~kg} / \mathrm{ha}$ was absorbed by the increased costs of production. This results in $12 \%$ more farmers earning less than the Living Income threshold (32\% of the farmers) compared with a yield increase without the additional investment of $30 \%$ (20\% of the farmers; Table 4 ).

\section{Broader Impacts of Increasing Cocoa Prices and Yields}

If the cocoa price or cocoa yields are increased as explored in the scenarios presented above this will undoubtedly have wider short and long term implications for the cocoa production sector as a whole. An increase in the cocoa price will both stimulate and enable producers to increase their yields, potentially resulting in larger income increases than those suggested here (Figures 4, 5). Both strategies may also provide an incentive for farmers to expand their cocoa area within their farms, replacing other crops or fallow land and reducing non-cocoa income. In the absence of strong governance, the economic incentives could also encourage expansion of cocoa production into forests (Wessel and QuistWessel, 2015; Fountain and Hütz-Adams, 2018). Increases in the overall amounts of cocoa produced lead to a surplus of supply and decreases in the world market price if demand does not increase at the same time, as has happened in the 2016/2017 cropping season (Fountain and Hütz-Adams, 2018). Both price and yield increases, therefore, may backfire unless policies are in place to manage international supply (Koning and Jongeneel, 2006; Fountain and Hütz-Adams, 2018). Such policies are only effective when producing countries join forces and set the necessary conditions. Options to do this include setting export quota and tariffs, liaising with producer organizations, assisting some producers to move out of cocoa to other sources of income (Odijie, 2018), paying producers a premium independent of their production, preventing countries from free riding, and perhaps even destruction of surpluses (Koning and Jongeneel, 2006). When such policies are in place, it may be safe to slowly allow production to increase, as global demand for cocoa continues to rise (ICCO, 2012, 2020).

\section{Income Diversification}

Another option which is frequently proposed is for cocoa producers to diversify their income, both on-farm and offfarm (Barry Callebaut, 2018; Cargill, 2019). On-farm income diversification implies including more (tree) crops or livestock on the farm, or adding value to farm products before they are sold. This leads to less reliance on a single (cash) crop and therefore reduces risks, which is especially important given the price volatility of cocoa and other commodities (Schroth and Ruf, 2014; Bymolt et al., 2018; Fountain and Hütz-Adams, 2018). Shifting to other (tree) crops and agroforestry are also potential adaptation strategies in the face of climate change, which already appears to reduce the area suitable for cocoa production in West Africa (Läderach et al., 2013; Fountain and Hütz-Adams, 2018; Abdulai et al., 2020). Furthermore, on-farm diversification can increase household food security due to improved seasonal and long-term stability of on-farm production, and improved dietary diversity either directly through consumption of farm produce or indirectly through increasing the income available to purchase food (Fountain and Hütz-Adams, 2018; Feliciano, 2019).

Cocoa-producing households in Ghana and Côte d'Ivoire already grow five (Ghana) or six (Côte d'Ivoire) different crops on average (Bymolt et al., 2018). In the KIT data, on average $67 \%$ (Côte d'Ivoire) or 62\% (Ghana) of income is derived from cocoa, indicating they are not as dependent on cocoa as suggested by other studies (Table 3, True Price, 2018). Dependency on cocoa appears to be only weakly linked to poverty, so diversification does not necessarily lead to a higher income (Figures 2G,H). Moreover, the initial investment required might limit diversification to better-off households (Feliciano, 2019). Lack of additional land and labor may also prohibit on-farm diversification (Figure 1). Tree crops such as cocoa are fixed assets which take time and capital to be replaced (Aneani et al., 2011; Schroth and Ruf, 2014). Cocoa producers cannot respond quickly to market or climatic signals and are only likely to move away from cocoa when benefits from other (tree) crops are higher for a prolonged period of time (Aneani et al., 2011; Schroth and Ruf, 2014; Abdulai et al., 2020). Cocoa is perceived by cocoa producers to be their most profitable crop in Ghana and Côte d'Ivoire, and if anything, the importance of cocoa has increased in recent years (Bymolt et al., 2018). Households have a variety of economic and noneconomic reasons to diversify and choose different crops, such as distribution of income and labor requirements over the year, suitability for household consumption, reliability of the market and other infrastructure, public policy, land availability, and tradition (Schroth and Ruf, 2014; Bymolt et al., 2018; Feliciano, 2019). Whether further diversification is profitable and desirable depends on the household's resources (e.g., land, capital, and labor) and on the enabling environment (e.g., infrastructure and marketability) (Figure 1, Bymolt et al., 2018).

Off-farm income may help to spread risk, and can complement farm income in the low season (Alobo Loison, 2015). Furthermore, off-farm income may provide potential for on-farm investments (leading to increased yields) and vice versa (Alobo Loison, 2015). Especially for those households with 
little land, off-farm diversification may be required to increase income (Feliciano, 2019). Unfortunately, poorer households are often less able to engage in high-return off-farm activities, e.g., salaried jobs, as they lack the starting capital and/or education required (Alobo Loison, 2015). Thus poorer households are often forced to engage in seasonal casual labor jobs, which are less beneficial to household welfare (Dzanku, 2015). Off-farm diversification requires an enabling environment including improved infrastructure, proximity to urban areas, access to education, and increased demand for non-food goods and services driven by higher per capita incomes (Alobo Loison, 2015). We found that the proportion of off-farm income is generally low, though it is higher in Ghana (mean $=17 \%$, median $=10 \%$ in the KIT data set) than in Côte d'Ivoire (mean $=10 \%$, median $=0 \%$ in the KIT data set) (Figure 2 ).

Overall, the scope for cocoa producers to increase their income through diversification seems limited. Cocoa is perceived as one of the most profitable crops, and especially for the poorest households, a lack of opportunities and resources prevents them from engaging in more attractive income-generating activities.

When devising strategies to help cocoa producers to increase their income, knowledge on the availability of land (family), labor, and capital, and any constraints faced regarding these resources is crucial as the suitability of options depend on availability of these resources. More in-depth research regarding the possibility and willingness to invest these resources is required to understand which options are most suitable for which households.

\section{Suggestions for Future Surveys}

Household survey data is pivotal to underpin our understanding of the income of cocoa producing households and the opportunities and constraints they face. Currently, different companies and organizations make huge investments in household monitoring, surveying thousands of households each year. The surveys of KIT and Ghent University aimed to gain insights into the overall population of cocoa-producing households in each country. By contrast the surveys conducted by WUR and Cargill were focused on cocoa producing households working within specific companies, certification schemes, or cooperatives, with the aim of providing baseline information against which changes could be monitored over time. The more general utility of such surveys would be enhanced if questionnaires are standardized and attention is paid to variables that are often overlooked, or for which only superficial information is collected.

Increasing cocoa yield is a key leverage point to increase household income (Figures 1, 5). In general, input costs per hectare (excluding labor costs) rise with increasing yields (see Supplementary Material 1), but the relationship is weak. In particular, more robust quantitative and qualitative information on the intensity and cost of input use and management practices is needed.

We were not able to include the contribution of food crops grown for household consumption or other sources of in-kind income to meet household needs in our analysis of household income. This is a shortcoming, given that food cost may comprise about half of household expenditure in less-developed countries when assuming all food is purchased (Donkoh et al., 2014; CIRES, 2018; Smith and Sarpong, 2018; Van De Ven et al., 2020). Such information is difficult to collect given the detail required, but excluding it may lead to a substantial underestimation of income for some households. More data could be collected to understand the dynamics of sharecropping, such as the division of costs, decision making, rights, and income from the sharecropped land between the sharecropper and the owner of the land. Especially in Ghana, many households are sharecroppers: $32-49 \%$ of the respondents were sharecroppers on at least part of their cocoa land, leading to an overestimation of household income (based on the data from KIT, WUR, and Ghent University). By contrast sharecropping was rare in Côte d'Ivoire, reported by only 1-5\% of the respondents (based on the data from KIT and WUR). Besides data related to cocoa production, data on other sources of on-farm and off-farm income is required. This includes information on the cultivation and marketing of other crops and land availability. Other variables of importance are availability and (opportunity) costs of household and hired labor.

To allow a more accurate comparison of households of different compositions to the Living Income benchmark, Van De Ven et al. (2020) suggest that the Living Income benchmark should be expressed on an AE basis. We found little difference in the number of households obtaining a Living Income when we recalculate the income data and the Living Income benchmark to income per $\mathrm{AE}$ rather than per person (Supplementary Material 2). Standardization of household surveys, using a common ontology of definitions, units, and variables included, and sharing data would enhance the utility and interpretability of the data collected, and reduce the effort and costs of all parties. Ultimately, this would lead to a better understanding of the households producing cocoa which will support the development of strategies to increase their income. The Rural Household Multi-Indicator Survey (RHoMIS; Hammond et al., 2017) provides an excellent basis for such a standardized survey questionnaire.

\section{CONCLUSIONS}

Our analysis shows that most cocoa producing households in Côte d'Ivoire and Ghana have difficulties to achieve a Living Income, and many fall below the poverty line. To allow comparisons among households, we expressed income on a per person basis. The key factors that determine income include the cocoa price, cocoa yields, number of household members, the land area on which cocoa is cultivated, and the contribution of non-cocoa income streams. To address poverty among cocoa producing households, the need to increase the price paid for cocoa to the producers is often emphasized. Our scenario analysis suggests that price increases will have limited effects on the income of households who now struggle the most, while benefits will mainly accrue to those who already earn more from cocoa. Of course this does not diminish the need to increase prices paid to farmers: currently, only $7 \%$ of the price consumers pay for chocolate reaches the cocoa producer (Solidaridad, 2020b). 
Cocoa remains an important income stream even of the poorest producers. Yet, it is important to realize that even drastic increases in the price of cocoa will not lead to an end of poverty for all cocoa producers.

Currently many research and development programmes focus on the sustainable intensification of cocoa production. By contrast with increases in price, poorer households stand to benefit the most from increases in productivity, as they often have the smallest current yields. However, especially poorer producers often lack the capital and labor required to achieve substantial increases in yield, and such investments pose a large risk.

Even when all possible strategies are considered, structural changes will be required in the long term to lift all producers out of poverty. Moreover, both income and yield increasing strategies would lead to increases in cocoa production which will lead to price drops when no international supply management policies are implemented. Besides conditions such as setting international export quota and tariffs, structural changes could include land reform (to increase farm sizes) in combination with adequate opportunities for off-farm income generation. These structural changes are not the sole responsibility of the companies involved in cocoa procurement. Concerted action is needed from the sector together with local and national governments to sustainably increase the income situation of cocoa producers in West Africa. Such action will need to be based on a shared assessment and understanding of the current income situation and resource availability of cocoa producers, underpinned by relevant and reliable data. To enhance utility and interpretability of household surveys and other data collection tools, we recommend that companies and organizations collecting farmer data develop a standardized set of (survey) data to be collected using a common ontology of definitions, units, and variables. Such advancements in the depth and standardization of data collection can then support the development of strategies to improve the incomes of cocoa producers and the sustainability of the cocoa sector as a whole.

\section{REFERENCES}

Abdulai, I., Hoffmann, M. P., Jassogne, L., Asare, R., Graefe, S., Tao, H.-H., et al. (2020). Variations in yield gaps of smallholder cocoa systems and the main determining factors along a climate gradient in Ghana. Agric. Syst. 181, 102812. doi: 10.1016/j.agsy.2020.102812

Alobo Loison, S. (2015). Rural livelihood diversification in SubSaharan Africa: a literature review. J. Dev. Stud. 51, 1125-1138. doi: 10.1080/00220388.2015.1046445

Aneani, F., Anchirinah, V. M., Owusu-Ansah, F., and Asamoah, M. (2011). An analysis of the extent and determinants of crop diversification by cocoa (Theobroma cacao) farmers in Ghana. Afr. J. Agric. Res. 6, 4277-4287. doi: 10.5897/AJAR10.1083

Aneani, F., and Ofori-Frimpong, K. (2013). An analysis of yield gap and some factors of cocoa (Theobroma cacao) yields in Ghana. Sustain. Agric. Res. 2, 117-127. doi: 10.5539/sar.v2n4p117

Assiri, A. A., Kacou, E. A., Assi, F. A., Ekra, K. S., Dji, K. F., Couloud, J. Y., et al. (2012). Rentabilité économique des techniques de réhabilitation et de replantation des vieux vergers de cacaoyers (Theobroma cacao L.) en Côte d'Ivoire. J. Anim. Plant Sci. 14,

\section{DATA AVAILABILITY STATEMENT}

Publicly available datasets were analyzed in this study. This data can be found here: https://dataverse.harvard.edu/dataset.xhtml? persistentId=doi10.7910/DVN/82TWZJ.

\section{AUTHOR CONTRIBUTIONS}

$\mathrm{JvV}$ and $\mathrm{KG}$ conceived the study. JvV conducted the analysis with guidance from KG and MS. JvV, KG, MS, and YW wrote the paper. All authors contributed to the article and approved the submitted version.

\section{FUNDING}

Funding for this research was provided by NWO/WOTRO (project W 08.250.305 and Strategic Partnership NL-CGIAR project 17231) and by the Norwegian Agency for Development Cooperation (NORAD) through the CocoaSoils program (grant RAF-17/0009; see www.CocoaSoils.org).

\section{ACKNOWLEDGMENTS}

We are grateful to Cargill Cocoa and Chocolate, Ghent University and the University of Ghana, the KIT Royal Tropical Institute, Solidaridad, UTZ (now Rainforest Alliance), IDH, Nestlé and Wageningen University \& Research (WUR), for sharing their datasets and/or answering our questions. We thank the editor and reviewers for their detailed comments and suggestions. All errors and omissions remain our responsibility.

\section{SUPPLEMENTARY MATERIAL}

The Supplementary Material for this article can be found online at: https://www.frontiersin.org/articles/10.3389/fsufs. 2021.732831/full\#supplementary-material

1939-1951. Available online at: https://www.m.elewa.org/JAPS/2012/14.2/ 3.pdf

Balineau, B., Bernath, S., and Pahuatini, V. (2016). "Cocoa farmers' agricultural practices and livelihoods in Côte d'Ivoire," in Insights from Cocoa Farmers and Community Baseline Surveys Conducted by Barry Callebaut Between 2013 and 2015. AFD and Barry Callebaut. Available online at: https://www.afd.fr/en/ ressources/cocoa-farmers-agricultural-practices-and-livelihoods-cote-divoire (accessed September 15, 2021).

Barry Callebaut (2018). Forever Chocolate Progress Report 2017/18. Available online at: https://www.barry-callebaut.com/sites/default/files/2019-01/barrycallebaut-forever-chocolate-progress-report-2017-18.pdf (accessed September 15, 2021).

Barry Callebaut (2021). Prospering Farmers 2019/20. Available online at: http://callebaut.com/en/group/forever-chocolate/sustainability-reporting/ prospering-farmers-201920 (accessed September 15, 2021).

Boserup, E. (1965). The Conditions of Agricultural Growth. New York, NY: Aldine.

Bymolt, R., Laven, A., and Tyszler, M. (2018). Demystifying the Cocoa Sector in Ghana and Côte d'Ivoire. Amsterdam: KIT Royal Tropical Institute. Available online at: https:/www.kit.nl/project/demystifying-cocoa-sector/ (accessed September 15, 2021). 
Cargill (2019). Connected for More - The 2017/2018 Cargill Cocoa and Chocolate Sustainability Report. Available online at: https://www.cargill.com/static/cocoasustainability/ (accessed September 15, 2021).

CIRES (2018). Living Income Report Rural Côte d'Ivoire - Cocoa Growing Areas. (Cocody, Côte d'Ivoire: Ivorian Center for Socio Economic Research (CIRES), University of Cocody).

Coulibaly, S. K., and Erbao, C. (2019). An empirical analysis of the determinants of cocoa production in Cote d'Ivoire. J. Econ. Struct. 8, 5. doi: 10.1186/s40008-019-0135-5

Donkoh, S. A., Hamdiyah, A., and Nkegbe, P. K. (2014). Food expenditure and household welfare in Ghana. Afr. J. Food Sci. 8, 164-175. doi: 10.5897/AJFS2013.1120

Dzanku, F. M. (2015). Transient rural livelihoods and poverty in Ghana. J. Rural Stud. 40, 102-110. doi: 10.1016/j.jrurstud.2015.06.009

Ellis, F. (1993). Peasant Economics. Chicago, IL: Aldine.

Ellis, F. (1998). Household strategies and rural livelihood diversification. J. Dev. Stud. 35, 1-38. doi: 10.1080/00220389808422553

Ellis, F., and Freeman, H. A. (2004). Rural livelihoods and poverty reduction strategies in four African countries. J. Dev. Stud. 40, 1-30. doi: $10.1080 / 00220380410001673175$

Fairtrade (2018). Cocoa Farmers to Earn More Thought a Higher FairTrade Minimum Price. Available online at: https://www.fairtrade.net/news/cocoafarmers-to-earn-more-through-a-higher-fairtrade-minimum-price (accessed June 2, 2020).

Fairtrade (2020). Cocoa. Available online at: https://www.fairtrade.net/product/ cocoa (accessed June 2, 2020).

Feliciano, D. (2019). A review on the contribution of crop diversification to sustainable development goal 1 "no poverty" in different world regions. Sustain. Dev. 27, 795-808. doi: 10.1002/sd.1923

Ferreira, F. H. G., Chen, S., Dabalen, A., Dikhanov, Y., Hamadeh, N., Jolliffe, D., et al. (2016). A global count of the extreme poor in 2012: data issues, methodology and initial results. J. Econ. Inequal. 14, 141-172. doi: 10.1007/s10888-016-9326-6

Fountain, A. C., and Hütz-Adams, F. (2015). Cocoa Barometer 2015. Available online at: http://www.cocoabarometer.org/Download.html (accessed September 15, 2021).

Fountain, A. C., and Hütz-Adams, F. (2018). Cocoa Barometer 2018. (accessed September 15, 2021).

Fountain, A. C., and Hütz-Adams, F. (2019). Necessary Farm Gate Prices for a Living Income. Cocoa Barometer Consortium, administered by the VOICE Network. Available online at: https://www.voicenetwork.eu/wp-content/ uploads/2020/01/200113-Necessary-Farm-Gate-Prices-for-a-Living-IncomeDefinitive.pdf (accessed September 15, 2021).

Hammond, J., Fraval, S., Van Etten, J., Suchini, J. G., Mercado, L., Pagella, T., et al. (2017). The Rural Household Multi-Indicator Survey (RHoMIS) for rapid characterisation of households to inform climate smart agriculture interventions: description and applications in East Africa and Central America. Agric. Syst. 151, 225-233. doi: 10.1016/j.agsy.2016.05.003

ICCO (2012). The World Cocoa Economy: Past and Present. London: International Cocoa Organisation.

ICCO (2019). Quarterly Bulletin of Cocoa Statistics, Vol. XLV, No.3, Cocoa year 2018/19. London: International Cocoa Organisation.

ICCO (2020). Quarterly Bulletins of Cocoa Statistics. London: International Cocoa Organisation. Available online at: https://www.icco.org/icco-documentation/ quarterly-bulletin- of-cocoa-statistics/ (accessed September 15, 2021).

Kongor, J. E., De Steur, H., Van De Walle, D., Gellynck, X., Afoakwa, E. O., Boeckx, P., et al. (2018). Constraints for future cocoa production in Ghana. Agroforest. Syst. 92, 1373-1385. doi: 10.1007/s10457-017-0082-9

Koning, N., and Jongeneel, R. (2006). "Food sovereignty and export crops. Could ECOWAS create an OPEC for sustainable cocoa?," in Regional Forum on Food Sovereignty (Niamey).

Läderach, P., Martinez-Valle, A., Schroth, G., and Castro, N. (2013). Predicting the future climatic suitability for cocoa farming of the world's leading producer countries, Ghana and Côte d'Ivoire. Clim. Change 119, 841-854. doi: 10.1007/s10584-013-0774-8

Living Income Community of Practice (2020). The Concept. Available online at: https://www.living-income.com/the-concept (accessed June 2, 2020).
Mars (2020). Saving Tomorrow's Cocoa, Today. Available online at:https://www. mars.com/sustainability-plan/cocoa-for-generations (accessed June 2, 2020).

Mondelēz International (2019). Cocoa Life Annual Report 2018.

Mondelēz International (2020). How We Measure Progress. Available online at: https://www.cocoalife.org/impact (accessed June 2, 2020).

Odijie, E. M. (2016). Diminishing returns and agricultural involution in Côte d'Ivoire's cocoa sector. Rev. Afr. Polit. Econ. 43, 504-517. doi: $10.1080 / 03056244.2015 .1085381$

Odijie, M. E. (2018). Sustainability winners and losers in business-biased cocoa sustainability programmes in West Africa. Int. J. Agric. Sustain. 16, 214-227. doi: 10.1080/14735903.2018.1445408

Peprah, K. (2019). "Cocoa plant, people and profit in Ghana," in Theobroma Cacao - Deploying Science for Sustainability of Global Cocoa Economy, ed P.O. Aikpokpodion (IntechOpen). Available online at: https://www.intechopen. com/books/theobroma-cacao-deploying-science-for-sustainability-ofglobal-cocoa-economy/cocoa-plant-people-and-profit-in-ghana (accessed September 15, 2021).

R Core Team (2018). R: A Language and Environment for Statistical Computing. 3.5.0 ed. Vienna: R Foundation for Statistical Computing.

Ravallion, M. (2000). "Poverty lines in theory and practice," in Living Standards Measurement Survey Working Paper No. 133. ed S. Editor (Washington DC: The World Bank).

Ravallion, M. (2008). "Poverty lines," in The New Palgrave Dictionary of Economics, eds S. N. Durlauf and L. E. Blume (London: Palgrave Macmillan) 5068-5073.

Ravallion, M., Chen, S., and Sangraula, P. (2009). Dollar a day revisited. World Bank Econ. Rev. 23, 163-184. doi: 10.1093/wber/lhp007

Reuters (2015). Poor Rains Raise Concerns Over Coming Ghana Cocoa Crop. Available online at: https://www.reuters.com/article/cocoa-ghana/poor-rainsraise-concerns-over-coming-ghana-cocoa-crop-idUSL3N1213RE20151001 (accessed May 20, 2020).

Reuters (2016). Harsh Winds, Lack of Rain to Hit Ghana Cocoa Output. Available online at: https://www.reuters.com/article/ghana-cocoa-harmattan/harshwinds-lack-of-rain-to-hit-ghana-cocoa- output-idUSL8N15N3QR (accessed May 20, 2020).

Reuters (2019). CORRECTED-UPDATE 1-Ivory Coast, Ghana Add 'Living Income' Cocoa Premium to Fight Poverty. Available online at: https://www.reuters.com/ article/westafrica-cocoa/corrected-update-1-ivory-coast-ghana-add-livingincome-cocoa-premium-to-fight-poverty-idUSL8N24B55M (accessed May 20, 2020).

Rowntree, S. B. (1901). Poverty: A Study of Town Life. London: Macmillan.

Ruf, F., and Bini, S. (2012). Cocoa and fertilizers in West-Africa. IDH. Available online at: https://issuu.com/idhsustainabletradeinitiative/docs/idh_cacao_6pager_cover_16_april_2 (accessed September 15, 2021).

Ruf, F., and Schroth, G. (2004). "Chocolate forests and monocultures: a historical review of cocoa growing and its conflicting role in tropical deforestation and forest conservation," in Agroforestry and Biodiversity Conservation in Tropical Landscapes, eds G. Schroth, G. Fonseca, C. Harvey, C. Gascon, H. Vasconcelos and A.-M. Izac. (Washington, DC: Island Press), 104-134.

Schroth, G., and Ruf, F. (2014). Farmer strategies for tree crop diversification in the humid tropics. A review. Agron. Sustain. Dev. 34, 139-154. doi: 10.1007/s13593-013-0175-4

Smith, S., and Sarpong, D. (2018). Living Income Report Rural Ghana - Cocoa growing areas of Ashanti, Central, Eastern and Western Regions. The Living Income Community of Practice. Available online at: https://cocoainitiative.org/ wp-content/uploads/2018/12/LIVING-INCOME-REPORT-FOR-GHANA. pdf (accessed September 15, 2021).

Solidaridad (2020a). Cacao. Available online at: https://www.solidaridad.nl/ supply-chains/cacao (accessed June 2, 2020).

Solidaridad (2020b). Kom in Actie Voor Winst Voor Iedereen. Available online at: https://www.solidaridad.nl/winstvooriedereen (accessed June 2, 2020).

Tittonell, P., and Giller, K. E. (2013). When yield gaps are poverty traps: the paradigm of ecological intensification in African smallholder agriculture. Field Crops Res. 143, 76-90. doi: 10.1016/j.fcr.2012.10.007

Tony's Chocolonely. (2018). Goed Nieuws: Fairtrade Gaat Hun Premie en Minimumprijs Verhogen! Available online at: https://tonyschocolonely. $\mathrm{com} / \mathrm{nl} / \mathrm{nl} /$ onze- missie/nieuws/goed-nieuws-fairtrade-gaat-hun-premie-enminimumprijs-verhogen (accessed June 2, 2020). 
Tony's Chocolonely. (2020). Samen Maken We 100\% Slaafvrij de Norm in Chocolade. 'T Probleem. Available online at: https://tonyschocolonely.com/nl/ $\mathrm{nl}$ /onze-missie (accessed June 2, 2020).

True Price (2018). Cocoa Farmer Income. The Household Income of Cocoa Farmers in Côte d'Ivoire and Strategies for Improvement. Fair Trade. Available online at: https://www.fairtrade.net/library/cocoa-farmer-income-the-householdincome-of-cocoa-farmers-in-cote-divoire-and-strategies-for-improvement (accessed September 15, 2021).

Tyszler, M., Bymolt, R., and Laven, A. (2018a). Analysis of the Income Gap of Cocoa Producing Households in Côte d'Ivoire. KIT Royal Tropical Institute.

Tyszler, M., Bymolt, R., and Laven, A. (2018b). Analysis of The Income Gap of Cocoa Producing Households in Ghana. KIT Royal Tropical Institute.

Tyszler, M., Bymolt, R., and Laven, A. (2018c). Demystifying the Cocoa Sector in Ghana and Côte d'Ivoire. KIT Royal Tropical Institute: Harvard Dataverse.

Van De Ven, G. W. J., De Valença, A., Marinus, W., De Jager, I., Descheemaeker, K. K. E., Hekman, W., et al. (2020). Living income benchmarking of rural households in low-income countries. Food Secur. 145, 309-323. doi: 10.1007/s12571-020-01099-8

Van Vliet, J. A., and Giller, K. E. (2017). "Mineral nutrition of cocoa: a review," in Advances in Agronomy, ed D. L. Sparks (London: Academic Press) 185-270.

Van Vliet, J. A., Schut, A. G. T., Reidsma, P., Descheemaeker, K., Slingerland, M., Van De Ven, G. W. J., et al. (2015). De-mystifying family farming: features, diversity and trends across the globe. Glob. Food Secur. 5, 11-18. doi: 10.1016/j.gfs.2015.03.001

Vanlauwe, B., Coyne, D., Gockowski, J., Hauser, S., Huising, J., Masso, C., et al. (2014). Sustainable intensification and the African smallholder farmer. Curr. Opin. Environ. Sustain. 8, 15-22. doi: 10.1016/j.cosust.2014. 06.001

Vigneri, M., and Kolavalli, S. (2018). Growth Through Pricing Policy: The Case of Cocoa in Ghana. Background Paper to the UNCTAD-FAO Commodities and Development Report 2017. Commodity Markets, Economic Growth and Development. Rome: FAO. Available online at: http://www.fao.org/3/I8329EN/ i8329en.pdf (accessed September 15, 2021).

Wessel, M., and Quist-Wessel, P. M. F. (2015). Cocoa production in West Africa, a review and analysis of recent developments. NJAS - Wagenin. J. Life Sci. 74-75, 1-7. doi: 10.1016/j.njas.2015.09.001

World Bank (1990). "World development report 1990: poverty," in World Development Report. New York.

World Bank (2017). "Ghana: agriculture sector policy note. Transforming agriculture for economic growth, job creation and food security," in Agriculture
Global Practice AFR01, Africa. The World Bank Groups. Available online at: http://documents.worldbank.org/curated/en/336541505459269020/pdf/ 119753-PN-P133833-PUBLIC-Ghana-Policy-Note-Ag-Sector-Review.pdf (accessed September 15, 2021).

World Bank (2018). Going Above And Beyond To End Poverty: New Ways Of Measuring Poverty Shed New Light On The Challenges Ahead. Available online at: https://www.worldbank.org/en/news/immersive-story/2018/10/17/goingabove-and-beyond-to-end-poverty-new-ways-of-measuring-poverty-shednew-light-on-the-challenges-ahead (accessed June 2, 2020).

World Bank (2019). World Development Indicators. Available online at: https:// databank.worldbank.org/reports.aspx? source=2andseries=PA.NUS.PRVT. PP,FP.CPI.TOTL,PA.NUS.FCRFandcountry=GHA,USA,CIV\# $\quad$ (accessed September 15, 2021).

World Cocoa Foundation (2017). "Learning as We Grow - Putting CocoaAction into Practice - CocoaAction Annual Report 2016." Available online at: https://www.worldcocoafoundation.org/wp-content/uploads/2016CocoaActionReport-English_WEB_10-30.pdf

World Cocoa Foundation (2020). Farmer Livelihoods. Available online at: https:// www.worldcocoafoundation.org/focus-areas/farmer-livelihoods/ (accessed June 2, 2020).

Zuidema, P. A., Leffelaar, P. A., Gerritsma, W., Mommer, L., and Anten, N. P. R. (2005). A physiological production model for cocoa (Theobroma cacao): model presentation, validation and application. Agric. Syst. 84, 195-225. doi: 10.1016/j.agsy.2004.06.015

Conflict of Interest: The authors declare that the research was conducted in the absence of any commercial or financial relationships that could be construed as a potential conflict of interest.

Publisher's Note: All claims expressed in this article are solely those of the authors and do not necessarily represent those of their affiliated organizations, or those of the publisher, the editors and the reviewers. Any product that may be evaluated in this article, or claim that may be made by its manufacturer, is not guaranteed or endorsed by the publisher.

Copyright (c) 2021 van Vliet, Slingerland, Waarts and Giller. This is an open-access article distributed under the terms of the Creative Commons Attribution License (CC $B Y)$. The use, distribution or reproduction in other forums is permitted, provided the original author(s) and the copyright owner(s) are credited and that the original publication in this journal is cited, in accordance with accepted academic practice. No use, distribution or reproduction is permitted which does not comply with these terms. 